\title{
An exceptionally long paleoseismic record of a slow-moving fault: The Alhama de Murcia fault (Eastern Betic shear zone, Spain)
}

\author{
María Ortuño ${ }^{1,2, \uparrow}$, Eulalia Masana², Eduardo García-Meléndez ${ }^{3}$, José Martínez-Díaz $^{4}$, Petra Štěpančíková5 \\ Pedro P. Cunha ${ }^{6}$, Reza Sohbati ${ }^{7}$, Carolina Canora ${ }^{4}$, Jan-Pieter Buylaert ${ }^{7}$, and Andrew S. Murray ${ }^{7}$ \\ ${ }^{1}$ Centro de Geociencias, Universidad Nacional Autónoma de México, Boulevard Juriquilla, 3001, 76230, Juriquilla, \\ Querétaro, México \\ ${ }^{2}$ RiskNat Group, Departament de Geodinàmica i Geofisica, Universitat de Barcelona, Martí i Franquès s/n, \\ 08028 Barcelona, Spain \\ ${ }^{3}$ Área de Geodinámica Externa, Facultad de Ciencias Ambientales, Universidad de León, Campus de Vegazana, s/n, \\ 24071 León, Spain \\ ${ }^{4}$ Departamento de Geodinámica, Universidad Complutense de Madrid, Calle Jose A. Novais, 28040 Madrid, Spain \\ ${ }^{5}$ Institute of Rock Structure and Mechanics, Academy of Sciences of the Czech Republic, V Holešovičkách 41, \\ 18209 Prague 8, Czech Republic \\ ${ }^{6}$ Department of Earth Sciences, IMAR-Marine and Environmental Research Centre, Universidade Coimbra, \\ Largo Marquês de Pombal, 3000-272 Coimbra, Portugal \\ ${ }^{7}$ Nordic Laboratory for Luminescence Dating, Department of Earth Sciences, Aarhus University, Ris $\phi$ DTU, \\ DK-4000 Roskilde, Denmark
}

\section{ABSTRACT}

Most catastrophic earthquakes occur along fast-moving faults, although some of them are triggered by slow-moving ones. Long paleoseismic histories are infrequent in the latter faults. Here, an exceptionally long paleoseismic record (more than 300 k.y.) of a slow-moving structure is presented for the southern tip of the Alhama de Murcia fault (Eastern Betic shear zone), which is characterized by morphological expression of current tectonic activity and by a lack of historical seismicity. At its tip, the fault divides into a splay with two main faults bounding the Góñar fault system. At this area, the condensed sedimentation and the distribution of the deformation in several structures provided us with more opportunities to obtain a complete paleoseismic record than at other segments of the fault. The tectonic deformation of the system was studied by an integrated structural, geomorphological, and paleoseismological approach. Stratigraphic and tectonic features at six paleoseismic trenches indicate that old alluvial units have been repeatedly folded and thrusted over younger ones along the different traces of the structure. The correlation of the event timing inferred for each of these trenches and

†E-mail: maria_ortuno@geociencias.unam.mx the application of an improved protocol for the infrared stimulated luminescence (IRSL) dating of K-feldspar allowed us to constrain a paleoseismic record as old as $325 \mathrm{ka}$. We identified a minimum of six possible paleoearthquakes of $M_{w}=6-7$ and a maximum mean recurrence interval of $29 \mathrm{k.y}$. This provides compelling evidence for the underestimation of the seismic hazard in the region.

\section{INTRODUCTION}

The identification and characterization of seismogenic faults are essential in areas without historical damaging seismicity, which is common in tectonic regions with low deformation rates.

The largest possible number of seismic cycles should be analyzed in order to better understand the seismic behavior of a fault. Given the length of the cycles of slow-moving faults (tens of thousands of years), the study of these faults entails long paleoseismic histories (hundreds of thousands of years). Our study is one of the few works to date that provides a long record of slow-moving faults.

Slow-moving faults are more difficult to investigate than fast-moving ones owing to their muted morphological expression and to the difficulty of obtaining and analyzing a long paleoearthquake record. The latter drawback is not only related to the time range of applica- bility of the current dating methods but also to the technical impracticality of excavating very deep trenches. If the seismic activity of a slowmoving fault is recorded in condensed sedimentary sequences (which are related to moderate to low sedimentation rates), trenches of only 2-3 $\mathrm{m}$ depth can provide a paleoseismic record of hundreds of thousands of years. We present an example of an exceptionally long paleoseismic record of a slow-moving fault affecting a condensed sedimentary alluvial sequence: the southern tip of the Alhama de Murcia fault.

In the Iberian Peninsula, the historical seismic record $(\sim 700 \mathrm{yr})$ is much shorter than the common recurrence interval of the Iberian seismogenic faults (>5000 yr). The Alhama de Murcia fault is a slow-moving fault with strong morphological expression of activity but with no record of historical surface-rupturing earthquakes. Nevertheless, on 11 May 2011, after the conclusion of this study, the Alhama de Murcia fault produced the most destructive earthquake in the Iberian Peninsula since 1881 (Andalusian earthquake, 25 December, EMS I = X; IGN, 2010). This $M_{w} 5.1$ event left thousands of people homeless and claimed nine fatalities in Lorca. The large number of people affected and the considerable economic loss caused by this moderate earthquake were mainly due to a shallow focus and a high peak acceleration of the ground in the most populated areas, which had been underestimated in the national seismic hazard 
plans (Martínez-Díaz et al., 2012a, 2012b). The recorded magnitude was much lower than the maximum expected magnitude $(\mathrm{M}>6)$ proposed in this work and in earlier paleoseismic studies in different segments of the Alhama de Murcia fault (Silva et al., 1997; Martínez-Díaz, 1998; Martínez-Díaz et al., 2001, 2003; Masana et al., 2004). This fault could therefore cause much more damage in the future.

We present the results of a thorough geomorphological, structural, and paleoseismic study carried out at the southern tip of the Alhama de Murcia fault in the proximity of Góñar (Fig. 1). We focused on this area for the following reasons: (1) It is located in an instrumental seismic gap; (2) there are no paleoseismic studies of this segment of the fault; and (3) some of its geomorphological, sedimentological, and geodynamical characteristics favor the preservation of a more complete paleoseismic record than adjacent segments.

We employed an improved method of luminescence dating to K-feldspar grains based on elevated-temperature infrared stimulated luminescence (post-IR IRSL or pIRIR) dating (Sohbati et al., 2011, and references therein). This method, described in the Methods section, allowed us to constrain much older paleoearthquakes than those previously dated by quartz optically stimulated luminescence (OSL) dating. The combined use of these methods provided us with an exceptionally long paleoearthquake record. The novel geochronological methodology could be useful in the study of surface processes and Quaternary geology.

Later herein, we highlight the significance of the results in terms of (1) the characteristic rupture of the faults under study, (2) the segmentation of the fault system during seismic events, and (3) the tectonic style in the study area. The unusually long paleoearthquake history is analyzed together with the histories obtained from earlier studies along other sectors of the Alhama de Murcia fault and Albox faults. This comparison offers new insights into the seismotectonic behavior of the faults in the Eastern Betic shear zone, which will have a considerable impact on seismic hazard assessment.

\section{GEOLOGICAL SETTING}

The Alhama de Murcia fault is located in the eastern part of the Betic Cordillera. This Cordillera is the northern branch of the Rif-Betic alpine orogenic belt, which resulted from the early Cenozoic collision between the African and Eurasian plates. The present-day relative plate motion has been estimated as 4.5-5.6 mm/yr (De Mets et al., 1994; McClusky et al., 2003). Within the Iberian margin, a large part of the shortening is accommodated by faults in the Eastern Betic shear zone and by internal deformation (Masana et al., 2004). Faults in the Eastern Betic shear zone (Bousquet, 1979; Banda and Ansorge, 1980; Sanz de Galdeano, 1990) are mainly left-lateral strike-slip structures oriented $\mathrm{N}-\mathrm{S}$ to ENE-WSW. Active faults in the Eastern Betic shear zone are the Alhama de Murcia fault, Carboneras, Palomares, Carrascoy, Bajo Segura, and San Miguel faults (Fig. 1A). All these faults are located in the internal zone of the Betic range, where the basement consists of a stack of tectonometamorphic complexes (Nevado-Filbride, Alpujárride, and Malaguide complexes; Fig. 1). In the eastern part of the range, the tectonic exhumation of these complexes during the main postcollisional period gave rise to a series of marine-continental tectono-sedimentary basins (Sanz de Galdeano and Vera, 1992; Rodríguez-Fernández and Sanz de Galdeano, 1992; Montenat, 1996). Most of these basins were bounded by extensional faults. Subsequently, Neogene to present-day tectonics reactivated many of these faults, giving rise to new intramontane sedimentary basins (Montenat and Ott d'Estevou, 1996; Bardají, 1999).

\section{Alhama de Murcia Fault}

The Alhama de Murcia fault is the longest fault in the Eastern Betic shear zone. First described by Montenat (1973) and Bousquet and Montenat (1974), this fault has been considered to be one of the most active faults in the Eastern Betics based on Quaternary geodynamical, geomorphological, and paleoseismologic data (e.g., Silva, 1994; Silva et al., 1992a, 1993, 1997; Martínez-Díaz, 1998; Martínez-Díaz et al., 2001, 2003; Masana et al., 2004). The tectonic activity of the Alhama de Murcia fault since the middle Miocene has been characterized by oblique left-lateral reverse kinematics (Montenat and Ott d'Estevou, 1996; MartínezDíaz, 1998).

The Pliocene-Quaternary Alhama de Murcia fault extends from Alcantarilla to Lorca, along an $\sim 100 \mathrm{~km}$ fault trace, according to recent neotectonic studies (e.g., Silva et al., 1997, 2003; Martínez-Díaz, 1998; Martínez-Díaz et al., 2003; Masana et al., 2004; Meijninger, 2006), although longer lengths have been proposed in earlier studies (e.g., Gauyau et al., 1977; Montenant et al., 1987) (Fig. 1A).

The Alhama de Murcia fault has been divided into different segments on the basis of its tectonic-geomorphological features, its geodynamical evolution, its subsurface geometry, and its historical and present-day seismicity (Silva et al., 1992a, 2003; Martínez-Díaz, 1998). To these criteria, Martínez-Díaz et al. (2012a) added the paleoseismic record and distinguished four segments, from $\mathrm{N}$ to $\mathrm{S}$ : Alcantarilla-Alhama (25 km); Alhama-Totana (11 km); Totana-Lorca (20 km); and Lorca-Góñar (40 km) (Fig. 1B). To the SW of the Lorca-Góñar segment, the Alhama de Murcia fault Pliocene-Quaternary activity is transferred to the Albox fault (Masana et al., 2005), and possibly to other active structures described by some authors (García-Meléndez, 2000; García-Meléndez et al., 2003, 2004; Meijninger, 2006; Pedrera et al., 2010).

\section{Historical and Instrumental Seismicity}

Since the beginning of the historic seismic catalog in the Iberian Peninsula, at around 1300 A.D. (IGN, 2010), some regions have experienced moderate to large earthquakes. Although the Alhama de Murcia fault is characterized by moderate to low $\left(\mathrm{M}_{\mathrm{w}}<5.5\right)$ instrumental seismicity, it has been identified as the possible seismogenic source of at least six damaging earthquakes occurring in 1579, 1674 (three of them), 1818, and 2011. These events produced maximum Medvedev-Sponheuer-Karnik intensities (MSK, very similar to MMI) between VII and VIII in Lorca in the central-southern part of the Alhama de Murcia fault (Fig. 1B). In the southern part of the Alhama de Murcia fault, a lack of historical and instrumental seismicity has been observed by Silva et al. (1997), Martínez-Díaz (1998), and Masana et al. (2004), among others. Although other faults in the area (such as the Palomares or the Albox fault) also reveal an absence of damaging historical earthquakes and a weak microseismicity (Fig. 1B), they have been shown to be seismogenic faults by means of paleoseismic studies (Silva et al., 1997; Masana et al., 2005).

\section{Earlier Paleoseismic Surveys in the Region}

In the proximity of Góñar, seven paleoseismologic sites have been studied: La Carraclaca, El Saltador, and El Colmenar sites along the Alhama de Murcia fault in the surroundings of Lorca; El Ruchete and Urcal sites at the Albox fault; and Aljibejo and Escarihuela sites at the Palomares fault. The main structural and paleoseismic results of these studies are summarized in Table 1 (see Fig. 1B for site location) and are discussed in this paper.

Most of the deformation observed in the paleoseismic studies listed in Table 1 prompted the authors (from Silva et al., 1997; Martínez-Díaz et al., 2003; García-Meléndez, 2000; GarcíaMeléndez et al., 2004; Soler et al., 2003; Masana et al., 2004; Masana et al., 2005) to assign earthquake magnitudes of up to $M=6-7$ to the seismic events recorded in the trenches. 
Figure 1. (A) Location of the study area within the Betic-Rif Cordillera (in the lower-left corner). The white arrow at the lower part of the figure represents the convergence rate between the Iberian and African plates. The faults marked with a thicker line constitute the Eastern Betics shear zone. CRF-Crevillente fault; BSF-Bajo Segura fault; SMF-San Miguel fault; $\mathrm{CF}$ Carrascoy fault; AMF_Alhama de Murcia fault; AF-Albox fault; PF-Palomares fault; CBF-Carboneras fault; $\mathrm{HOB}$ Huercal-Overa Basin; LBLorca Basin; GDD-Guadalentín depression; GD-Garita del Diablo. The plate convergence slip vector is indicated by a white arrow. (B) Seismicity of the historical catalog (IGN, 2010) projected over a shaded relief map. Note the gap in instrumental-historical seismicity for the southwestern tip of the Alhama de Murcia fault. Previous paleoseismological sites in the area are indicated: $1-\mathrm{El}$ Ruchete-Urcal; 2-Aljibejo and Escarihuela; 3-La Carraclaca; 4-El Saltador-El Colmenar. Other localities: PB-Pulpí Basin; ESR-Esuña Range; CRCarrascoy Range; LTR-La Tercia Range; ER-Enmedio Range.
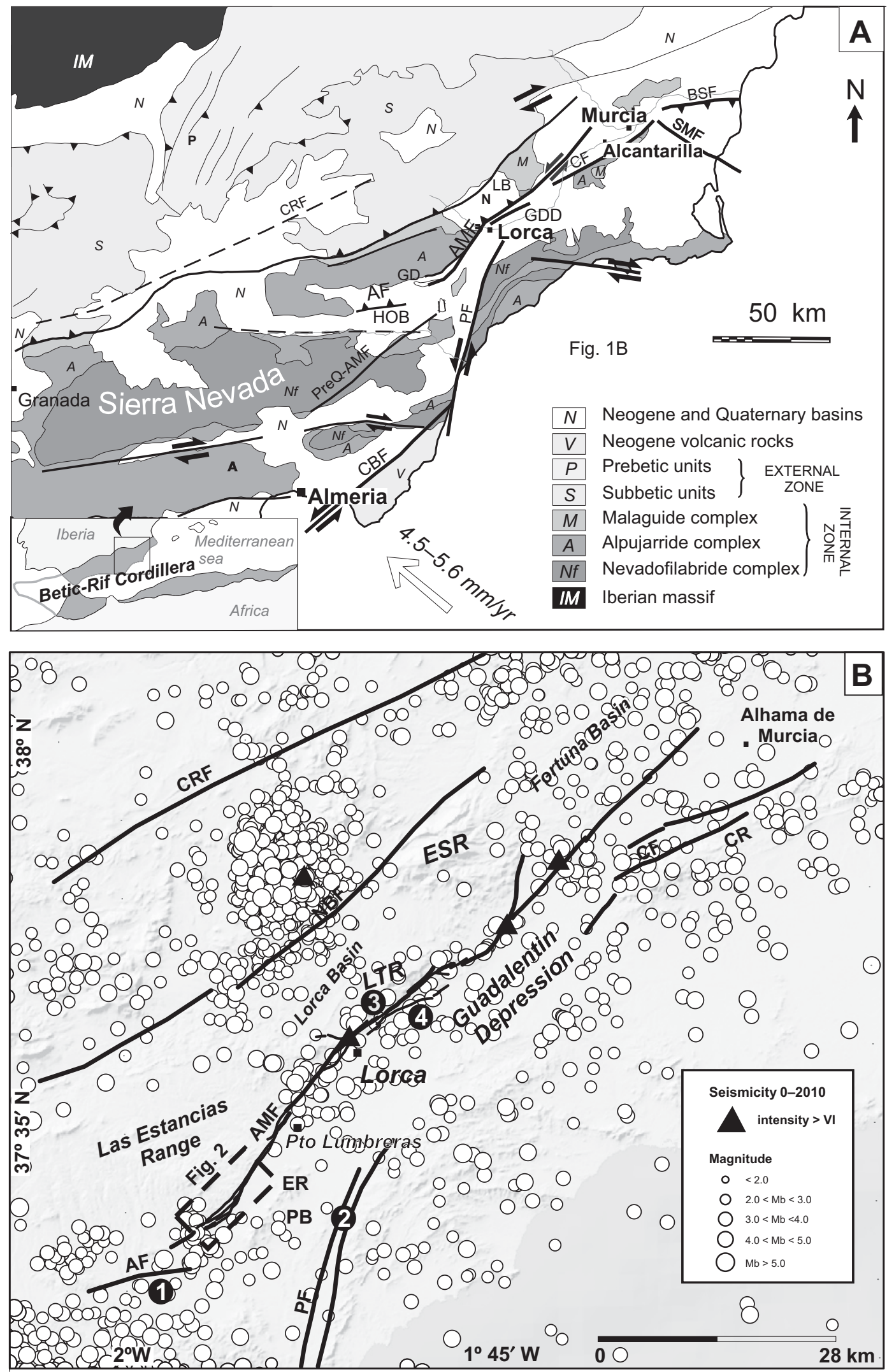


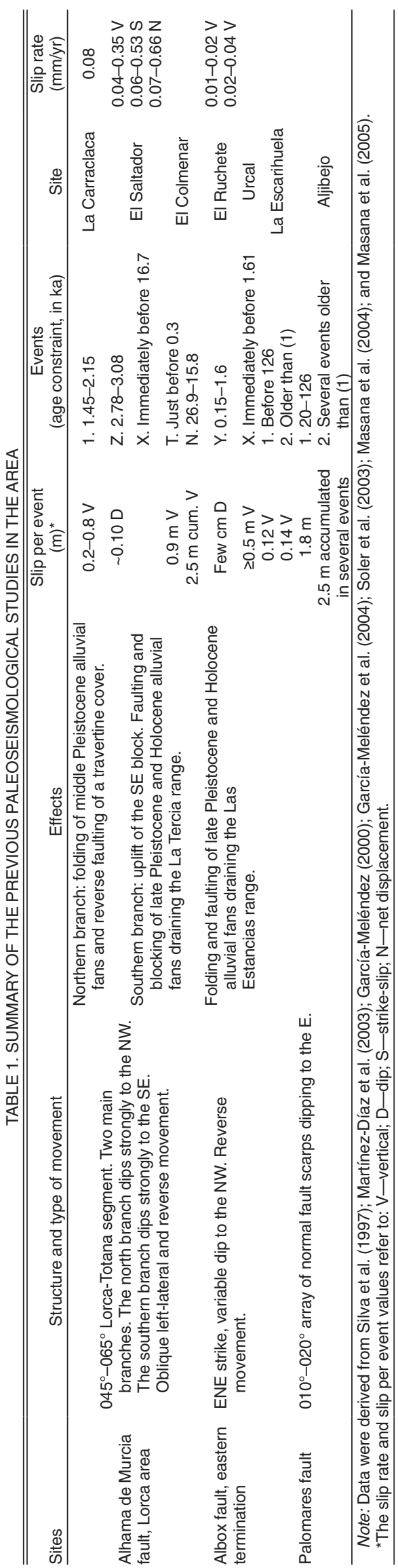

\section{METHODS}

We studied the geomorphology and structure of the southern tip of the Alhama de Murcia fault with the aid of aerial photographs (scale: $1: 33,000$ and 1:18,000) and field reconnaissance and mapping using ortho-images and 1:10,000 scale topographic maps. A paleoseismic study was performed at six trenches in the Góñar fault zone (Fig. 2). All the trenches were 2-3 m deep, with the exception of Carrascos-1, which is a natural outcrop on the northern margin of Carrascos Creek. At this site, $\sim 0.5 \mathrm{~m}$ of material was scraped off the wall to clean the exposure. The trenches varied in length (from $18 \mathrm{~m}$ to $50 \mathrm{~m}$ ) and were all excavated perpendicular to the fault trace, except Carrascos-1, which was slightly oblique to it. We installed a $1 \mathrm{~m}$ grid ( $2 \mathrm{~m}$ locally at the Carrascos-1 and Tio Rey trenches) and used photo-mosaic and graph paper to log the paleodeformation recorded at the trenches.

\section{Dating of Quaternary Units}

Dating deformed units is essential for constraining the age of the paleoearthquakes and for calculating the slip rates attributed to each of the faults. The age constraints in this work were derived from quartz thermoluminescence (TL) dating and $\mathrm{K}$-feldspar elevated-temperature infrared stimulated luminescence (pIRIR) dating of sediments. The results of the dating are given in Table 2.

\section{K-Feldspar Post-IR IRSL (pIRIR) Dating}

The material sampled for dating consists of fine sand or mud with a high concentration of felsic minerals. One of the advantages of analyzing K-feldspar is that older samples can be dated given that its luminescence signal can grow to doses that are much higher than those for quartz. However, the luminescence signal from K-feldspar is not often thermally stable (this phenomenon is called anomalous fading), with the result that special care must be taken to evaluate and correct the loss of signal during the burial time of the sample.

An improved protocol of infrared stimulated luminescence (IRSL) dating of K-feldspar based on those proposed by Thomsen et al. (2008) and Buylaert et al. (2009) was followed to obtain the accumulated doses in the samples from paleoseismic trenches at Gónar. Radionuclide concentrations were measured by high-resolution gamma spectrometry to estimate the dose rate. In the pIRIR dating procedure (see Sohbati et al., 2011), the IRSL signal is measured at an elevated temperature (e.g., $225{ }^{\circ} \mathrm{C}$ for $100 \mathrm{~s}$ ) after an infrared bleach at a low temperature (e.g., $50{ }^{\circ} \mathrm{C}$ for $100 \mathrm{~s}$ ). K-feldspar pIRIR fadingcorrected ages were considered to be the best age estimates of the samples.

\section{SOUTHERN TIP OF THE ALHAMA DE MURCIA FAULT: THE ALHAMA DE MURCIA FAULT-GÓÑAR FAULT SYSTEM}

The southern tip of the Alhama de Murcia fault represents the tectonic boundary between the Las Estancias range (uplifted block) and the Guadalentin and Huercal-Overa basins (downthrown block) (Fig. 1B). The Pliocene-Quaternary infill of these basins mainly consists of siliciclastic alluvial fans and minor fluvial system deposits and carbonate rocks. These deposits overlie a folded and faulted sequence of marine marl with interbedded conglomerate and evaporite of the late Miocene (Briend, 1981; Silva, 1994; Martínez-Díaz, 1998; García-Meléndez et al., 2003). The late Miocene and Pliocene-Quaternary rocks in this area are part of a fan-like structure interpreted as a cumulative wedge or progressive unconformity (García-Meléndez et al., 2003). The geological units exposed at the Las Estancias range consist of a Permian and older metamorphic basement (mainly schist, phyllite, and marble) and a sedimentary cover. The cover is of Miocene age and contains mainly red conglomerate interbedded with silt, sand, and evaporite (Voermans et al., 1978) (Fig. 2).

The geomorphology of the northeastern and southwestern parts of the study area has been mapped by Silva (1994) and Silva et al. (1992b), and by García-Meléndez (2000), respectively. The Quaternary active deformation of the Góñar area has previously been reported only by Briend (1981), who addressed local deformation of Quaternary alluvial fans affected by reverse faulting and by folding with a $070^{\circ}-$ $080^{\circ}$ axis trend. These Quaternary alluvial fans overlie late Miocene marls and turbidites in the El Judio Creek (Fig. 2). According to Briend, the reverse faults offset the Quaternary deposits by a few meters.

Figure 2 shows the main geomorphological units of the area and the traces of the main structural features. Morphological and sedimentary features such as alluvial fans, slope deposits, fluvial terraces, and faceted spurs were mapped. We classified the Quaternary alluvial fans as G0 (for the deposits of the present-day active drainage) to G6 (for the oldest recognizable alluvial fan). In most cases, the younger alluvial fans are incised in the older ones in an offlap depositional style. This entrenching of the alluvial system seems to be closely related to the ongoing tectonic uplift of the area. Some alluvial fans are 


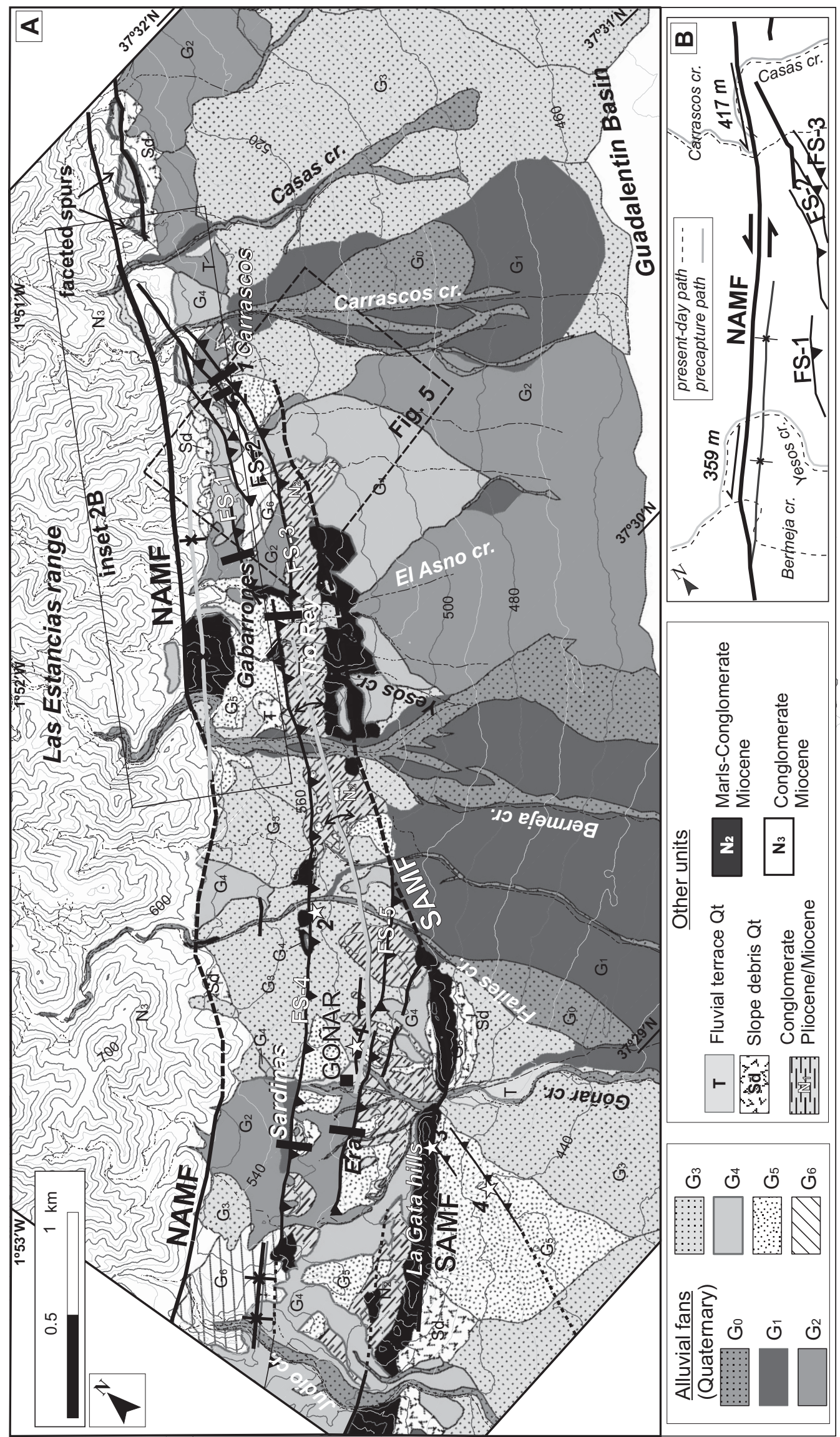

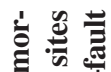

范的

至苛苛

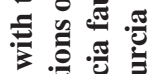

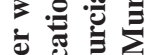

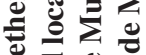

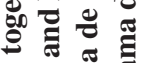

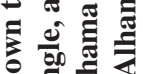

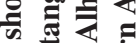

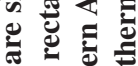

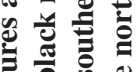

항

늘

者 零

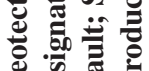

造

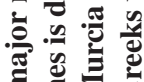

Е

ฮ่ छี

䒿

总氮

ڤั

कै

䨔产结

ส

डें

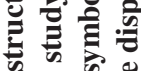

की

릉 훙ㅎㅇ

芯它

远它

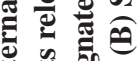

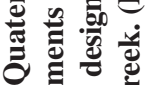

<卷

i 氜

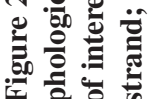


Ortuño et al.

TABLE 2. DATING RESULTS OF THE STRATIGRAPHIC UNITS SAMPLED

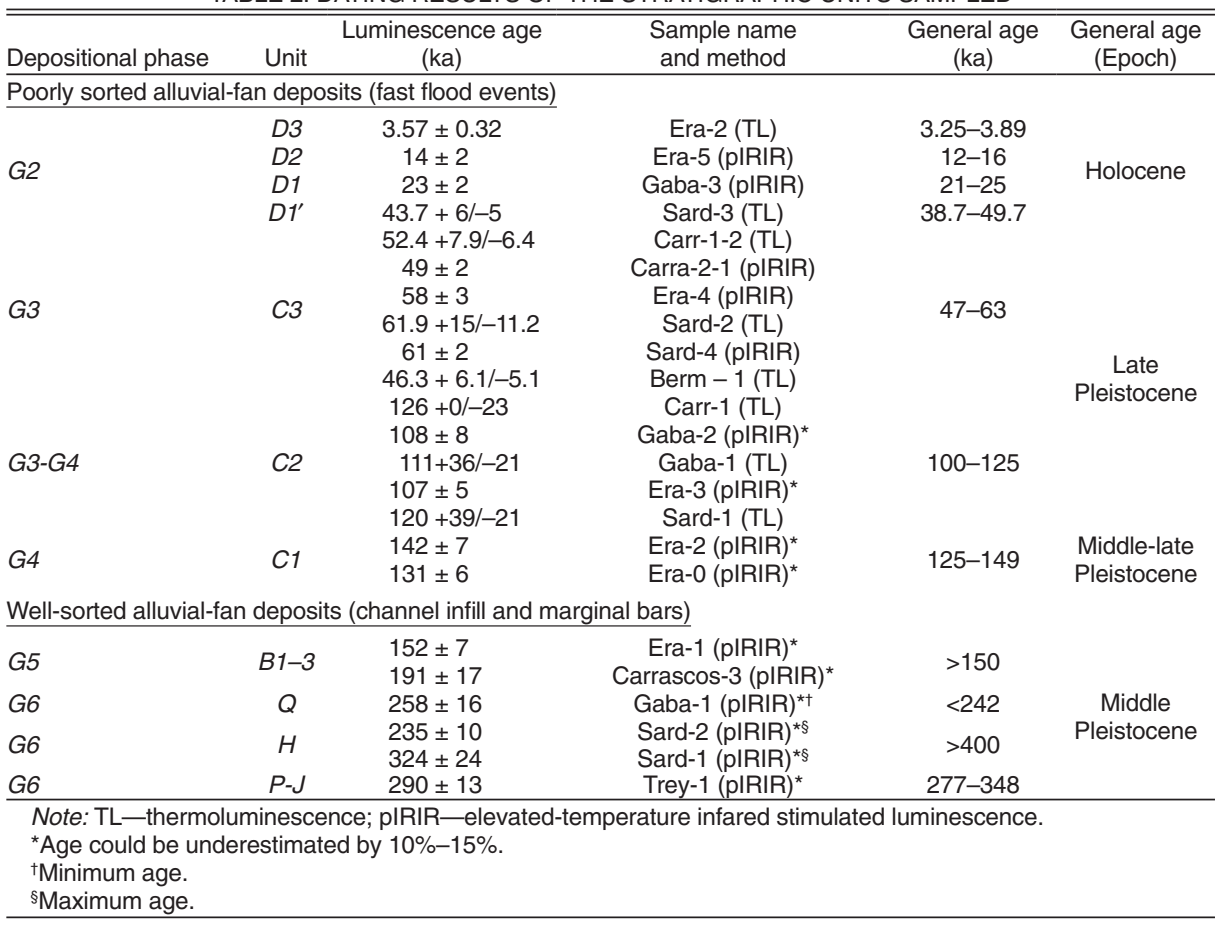

locally blocked in the distal area by the tectonic uplift of blocks in the Guadalentín Basin. The distal part of the alluvial fans has an anomalous rectilinear shape where this blockage occurs.

The southern tip of the Alhama de Murcia fault at Góñar forms a splay-like structure termed the Alhama de Murcia fault-Góñar fault system. This system of faults is made up of (1) two boundary faults, the northern Alhama de Murcia fault and the southern Alhama de Murcia fault, and (2) several internal structures, known as the Góñar faults (strands 1, 2, 3, and 5, henceforth, FS1 to FS5). The minimum length of the fault splay is $\sim 6 \mathrm{~km}$. This value might be an underestimation of the real length because it was calculated from geomorphological mapping where the morphology of Quaternary alluvial fans is preserved (Fig. 2). To the SW, the Quaternary faulting is not evident since only subvertical Miocene-Pliocene strata crop out along the Garita del Diablo structural high (Fig. 1B), and no clear geomorphological markers are preserved.

Two main features make the Alhama de Murcia fault-Góñar fault system more suitable than the northernmost segments of the Alhama de Murcia fault for the preservation of a complete paleoseismic record. First, the fault zone is made up of several strands of oblique to parallel faults. This configuration is more suitable for the record of paleoearthquakes than fault segments with a single trace and with a continuous orientation. This is attributed to the greater spatial coverage associated with a wider fault zone, which is usually related to a larger variety of erosive and sedimentological environments than a discrete fault zone. Second, the orthogonal orientation of some parts of the Alhama de Murcia fault-Góñar fault system with respect to the NW-SE convergence between the African and Iberian plates gives rise to more vertical displacements than the northernmost fault segments. This maximum vertical slip compensates for the small slip per event at the tips of fault systems.

\section{Northern Alhama de Murcia Fault}

The northern structural boundary of the Alhama de Murcia fault-Góñar structure, i.e., northern Alhama de Murcia fault, consists of a single (locally double) trace and defines the Las Estancias range front in the study area. The fault affects Miocene red sand and conglomerate, and to a lesser degree, Pliocene-Quaternary conglomerate (Fig. 2). Near El Judio Creek, the northern Alhama de Murcia fault is characterized by a centimetric dark-gray and yellow fault gouge. The fault plane has a $030^{\circ} / 70^{\circ}-80^{\circ} \mathrm{NW}$ orientation and slickenlines with a $55^{\circ}$ pitch to the SW. These data and the geomorphology of the area indicate that the NW block of the northern Alhama de Murcia fault is being uplifted with a southeastward component. At the northern end of the study area, the northern Alhama de Murcia fault is a 20-30-m-wide fault zone consisting of three fault strands. Two fault orientations were observed in this fault zone: $015^{\circ} / 60^{\circ}-70^{\circ} \mathrm{NW}$ and $040-060^{\circ} / 80^{\circ} \mathrm{NNW}$. Minor secondary faults with a $100^{\circ} / 85^{\circ} \mathrm{N}$ orientation and showing slickenlines with a pitch $80^{\circ}$ to the $\mathrm{W}$ were identified.

The strongest evidence for Quaternary deformation along the northern Alhama de Murcia fault includes faceted spurs along part of the range front, and the left-lateral deflections of the older channels of Bermeja and Casas Creeks. In both creeks, the old channel to the SE of the fault was displaced clockwise and was abandoned. The channel abandonment was probably related to a capture process linked to headward erosion of the creek to the SW. The left strikeslip deflections of the channel are $359 \pm 14 \mathrm{~m}$ at Bermeja Creek and $417 \pm 26 \mathrm{~m}$ at Casas Creek (Fig. 2B). It was not possible to undertake a paleoseismic study of this fault because of the absence of Pliocene-Quaternary depositional units and geomorphological markers that could be correlated on both sides of the northern Alhama de Murcia fault trace.

\section{Southern Alhama de Murcia Fault}

The southern Alhama de Murcia fault is the southern boundary fault of the Alhama de Murcia fault-Góñar structure. Its activity has produced an elongated tectonic high, the La Gata hills, parallel to the northern Alhama de Murcia fault trace (Figs. 2 and 3). The strata in the La Gata hills form a cumulative wedge (or progressive unconformity) representing the northeastern continuation of the La Garita del Diablo topographic high, described by García-Meléndez et al. (2003). Beds forming the wedge dip to the $\mathrm{SE}$ at angles ranging from $80^{\circ}$ (Neogene marls) to $60^{\circ}-50^{\circ}$ (Pliocene-Quaternary conglomerate) and $30^{\circ}$ (possibly early Pleistocene limestone and conglomerate).

The southern Alhama de Murcia fault crops out at site 3 (Fig. 2A) and is covered by Quaternary sediments to the NE of La Gata hills. The fault was identified as a 5-8-m-wide fault zone with a $060^{\circ}-070^{\circ} / 85^{\circ} \mathrm{N}$ orientation showing slickenlines with a $5^{\circ}-10^{\circ}$ pitch to the SW (Fig. $4 \mathrm{~K})$. The fault zone is characterized by a fault breccia and a fault gouge and by a local and sudden change in the dip of the conglomeratic beds, which are interpreted as part of rotated blocks. The continuation of the southern Alhama de Murcia fault to the north can be inferred by the left-lateral offset of (1) the La Gata hills, which are displaced by $\sim 1 \mathrm{~km}$ in the outwash zone of the Fraile and Bermeja Creeks (probably related to the folding of the fault trace, so that the NESW-oriented segment has a major strike-slip component, whereas the ENE-WSW segment 


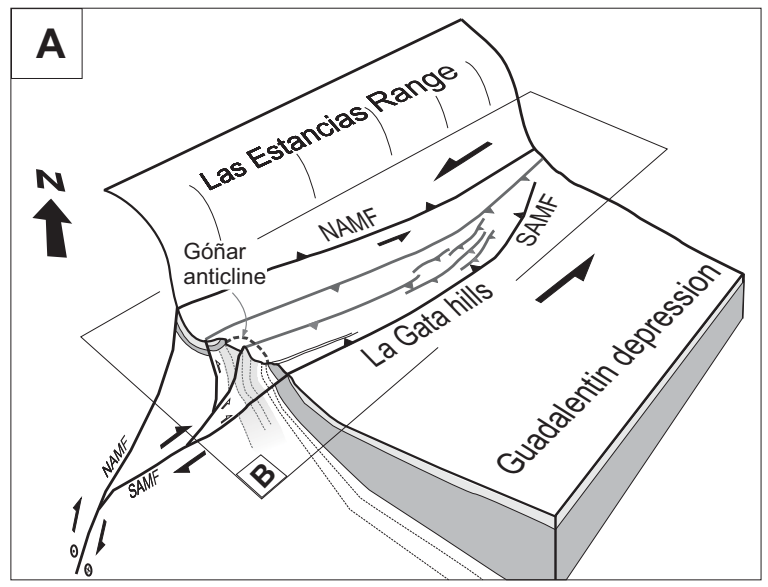

Figure 3. (A) Structural sketch of the Gónar structure along a NW-SE transect. Data come from field observations and subsurface information. Secondary faulting and folding are not included for simplicity. (B) Sketch of the Gónar structure with location of the four strands (FFS1 to FFS4) and trenches (black rectangles). NAMF-northern Alhama de Murcia fault; SAMF-southern Alhama de Murcia fault.

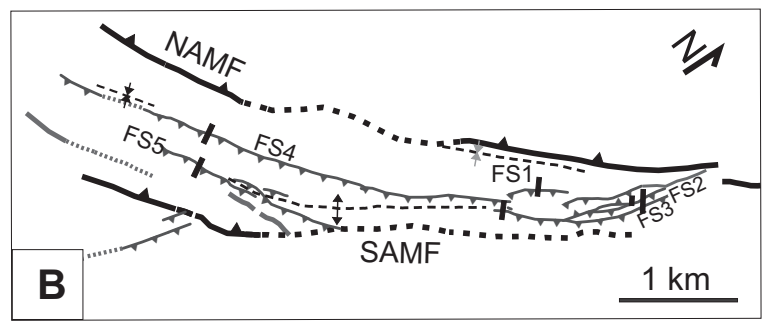

is active as a major reverse fault) and (2) two adjacent creeks (channels b and c in Fig. 5) between Carrascos and Yesos Creeks, which are displaced by $127 \pm 6 \mathrm{~m}$ and $77 \pm 10 \mathrm{~m}$, respectively. The present-day configuration of the drainage network in this area suggests that the southernmost creek was displaced and then captured by a straighter channel (channel a), resulting in the abandonment of part of the channel, which was displaced toward the NE (channel b).

Another fault with a $020^{\circ} / 80^{\circ} \mathrm{NW}$ orientation and slickenlines pitching $30^{\circ}$ to the north was observed a few meters to the SE of the southern Alhama de Murcia fault outcrop along the main road to Góñar (site 3, Fig. 2A). The fault cuts Pliocene-Quaternary bioclastic and brecciated limestone. Another fault can be observed at a quarry in the neighborhood (site 4, Fig. 2A).

The fault has a reverse component that can be deduced from the apparent vertical displacement of alluvial-fan G5 ( 1 m; Fig. 4I). It is not possible to ascertain whether the fault continues to be active because of the agricultural transformation of the land.

\section{Góñar Fault System}

The Gónar fault system is located between the northern Alhama de Murcia fault and the southern Alhama de Murcia fault. The splay consists of subparallel fault strands trending NNE-SSW (FS1-5 in Figs. 2A and 3). The faults are almost vertical or dip steeply toward the SE, parallel to the Neogene strata in most cases. In the southern part, the Góñar fault system consists of two strands (FS4 and FS3). In the northern part, next to the linkage with the northern Alhama de Murcia fault, the Gónar fault system is made up of three strands (FS1, FS2, and FS3). FS2 has an associated antithetic fault forming a push-up structure. Other minor faults offset the Quaternary alluvial fans by only a few centimeters and are considered secondary structures. Further details of the Góñar fault system are discussed later herein on the basis of the paleoseismological analysis.

The combined activity of the Góñar faults and the southern Alhama de Murcia fault has given rise to a wide anticline (the Gónar anticline) strata (Figs. 2 and 3). This structure has, at present, the shape of a stripped anticline, resulting in the outcrop of the underlying Miocene basement (Figs. 4C and 4D). The high erodibility of the outcropping marls led to the formation of an elongated erosional depression (between the $\mathrm{La}$ Gata hills and the Las Estancias range in Fig. 2A). This depression acted as a trap for the Quaternary alluvial fans, which have been deformed locally by the Góñar fault system. Recent activity of the fault system was only detected where Quaternary deposits are preserved.

\section{Structure at Depth}

Figure 3 shows a sketch of the main structures observed in the area and their hypothetical continuation at depth. The proposed model regards the structure as a compressional bend bedeforming Miocene and Pliocene-Quaternary tween the northern Alhama de Murcia fault and the southern Alhama de Murcia fault. Part of the Quaternary deformation in this compressional zone occurs in the Góñar fault system.

The opposite dip of the northern Alhama de Murcia fault and southern Alhama de Murcia fault with respect to the Góñar faults suggests complexity at depth. The northern Alhama de Murcia fault dips to the NW and is left-lateral reverse, with the result that the northwestern block is uplifted to the SE. The geometry and kinematics are consistent with geomorphological and structural data reported for the contiguous northern segments (Silva et al., 1997, 2003; Martínez-Díaz, 1998; Meijninger, 2006). By contrast, the faults in the Góñar fault system dip steeply to the SE and have a reverse component with an uplifted southeastern block (Figs. 2A, 3 , and 6).

The southern Alhama de Murcia fault is almost vertical at the surface and probably dips more gently to the NW at depth, where it probably merges into the northern Alhama de Murcia fault. The Góñar faults, located between these faults, dip steeply to the NE, so that they probably merge at depth into the southern Alhama de Murcia fault (Fig. 3). The blocks bounded by the Gónar faults have been uplifted to accommodate the shortening in the area.

The southern Alhama de Murcia fault may be assumed to be a detachment zone below the Góñar fault system. The displacement of the middle-late Quaternary channels, which is attributed to this fault (Fig. 5), attests to its recent activity. This accounts for the progressive tilting of Neogene and Pliocene-Quaternary layers that make up the cumulative wedge that crops out at the Garita del Diablo and La Gata hills (Figs. 1 and 2).

\section{TRENCHING ANALYSIS}

Our paleoseismic study focused on the Góñar fault system, owing to multiple sites showing deformation of middle-late Quaternary cover, in contrast to the absence of Quaternary deposits overlying the traces of the northern Alhama de Murcia fault and southern Alhama de Murcia fault (Fig. 2A)

Six trenches were excavated on the strands of the Gónar system. Three of them were located in the northern area on faults FS1, FS2, and FS3, and the other three trenches were placed in the central-southern part of the system on FS4 and FS5 (Figs. 2A and 3). Faulted alluvial-fan deposits are exposed at the trenches. The source areas of the alluvial fans are located on late Tortonian red conglomerate, cropping out along the southeastern border of the Las Estancias range. Units $\mathrm{P}-\mathrm{J}, \mathrm{Q}, \mathrm{B}$, and $\mathrm{C} 1$ at the trenches 
correspond to the oldest alluvial fans (alluvial phases $\mathrm{G} 4$ to G6). The youngest alluvial phases (G0 to G3) are represented by units C2-C3 and D (Figs. 2 and 6; Table 2). These units are folded and faulted, giving rise to tectonic highs that blocked the youngest alluvial-fan deposits, which are also locally deformed, albeit to a lesser degree.

The following sections present the descriptions of the trenches. The stratigraphy of the units observed at the trenches is summarized in the legend in Figure 6. Table 2 compiles the facies interpretation of each unit and its TL and pIRIR ages. The pIRIR age was used whenever a unit was dated through TL and pIRIR methods in order to provide the most uniform chronology.

At each trench, different markers were used to measure the deformation along the exposed faults. We assigned an uncertainty value (ranging from $2 \%$ to $21 \%$ of the mean value) to the displacement values measured in each case. This value depended on the degree of clarity of the contact. Only one measurement had a much larger uncertainty, this being almost $50 \%$ of the mean value.

A minimum of 15 events (summarized in Table 3) was identified, some of them possibly corresponding to the same earthquake observed at different trenches. The identification of the events was based on (1) the fault displacement of the present-day soil, (2) the sealing of a fault by a younger unit, (3) the displacement of a fault by another fault, (4) the angular unconformity between two adjacent units, (5) a sudden change in the sedimentary conditions due to a possible tectonic origin, and (6) the formation of a colluvial wedge interpreted as the collapse of a fault scarp.

The time range of each event was determined by using the ages of the postdating and predating units at its trench (Table 3). For some cases, those ages were not available. Then, we used the age for those units at the closest trenches.

\section{Carrascos Site (Strands 2 and 3)}

Carrascos corresponds to the area where the Alhama de Murcia fault changes from a single trace to a splay of different fault strands. Two trenches separated by $\sim 80 \mathrm{~m}$ were studied at this site: Carrascos- 1 to the NE, and Carrascos- 2 to the SW (Figs. 2, 3A, 6A, 6B, and 6C). The activity of the faults has led to the formation of several hills blocking the alluvial sediments of the small creeks to the SE of Carrascos Creek.

Three depositional phases are observed at Carrascos-1: an older phase (G5) represented by unit $\mathrm{B}$, an intermediate phase (G4 and G3) consisting of units $\mathrm{C} 1$ to $\mathrm{C} 3$, and a younger phase (G2) made up of units D1 and D2. These alluvial deposits are overlain by a soil unit.
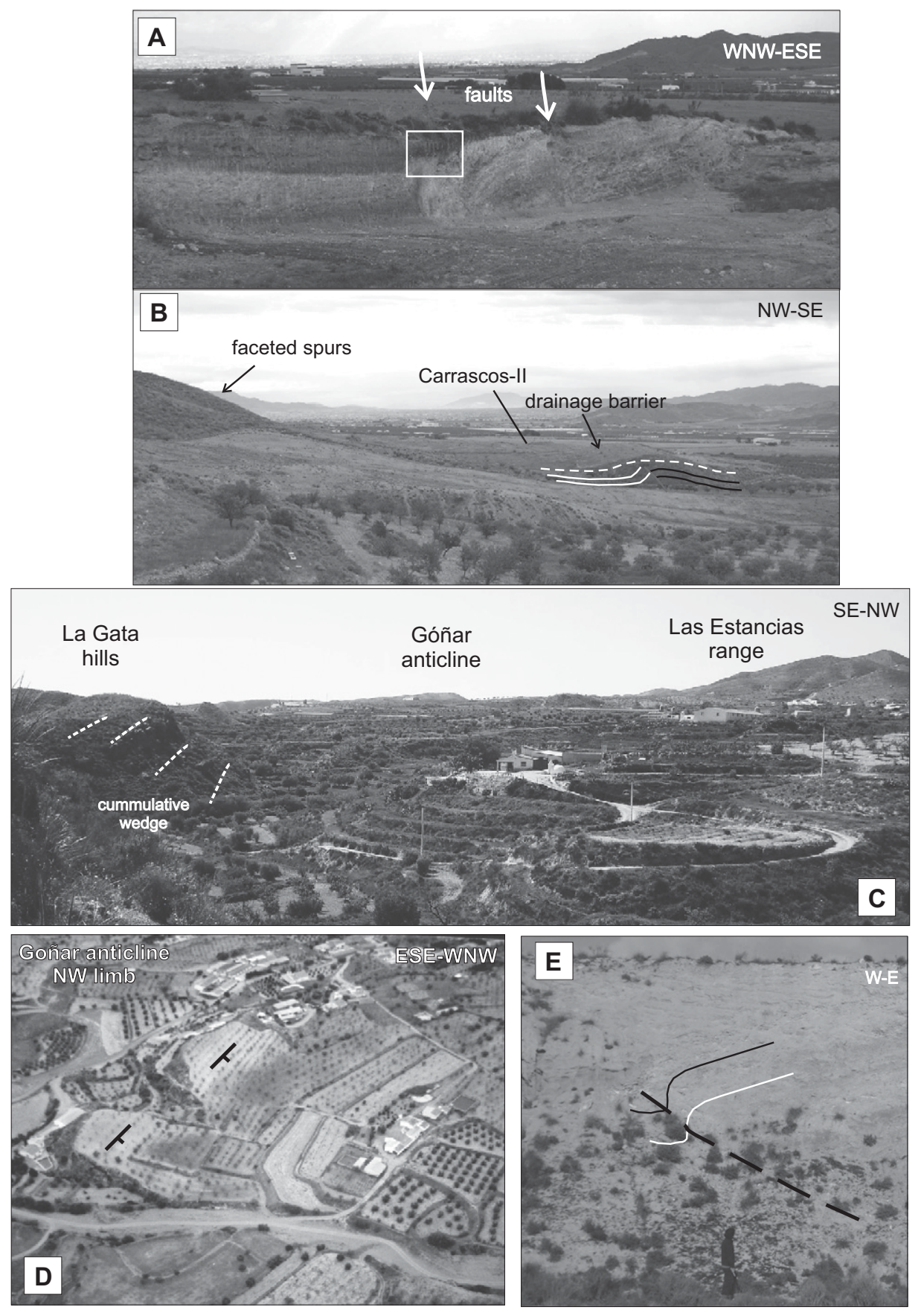

Figure 4 (on this and following page). General view and detail of deformation observed at several natural and artificial outcrops in the study area. (A) Carrascos-1 trench. The white box indicates location of photograph G. (B) View of the Gónar fault strand (FS) 2 with a sketch of its associated drag fold. (C) View of the lowlands associated with the Gónar anticline. The La Gata hills correspond to the SE limb of this anticline. (D)View of the PlioceneQuaternary strata of the NW limb of the Gónar anticline at site 2. (E) Reverse faulting of the beds of the G-4 alluvial phase at site 4 .

With the exception of the upper part of D1, all units are faulted and/or folded. Four faults are exposed at the trench. The northwestern fault corresponds to the Gónar FS2, which dips $\sim 15^{\circ}$ to the $\mathrm{SE}$ and displaces unit $\mathrm{C}$ and the base of D1 (Fig. 6B). The other three faults correspond to FS3, and are termed faults a, $\mathrm{a}^{\prime}$, and $b$. Fault a is vertical, and faults $a^{\prime}$ and $b$ dip $45^{\circ}$ and $40^{\circ}$ to the SE, respectively. Faults $\mathrm{a}^{\prime}, \mathrm{b}$, and FS2 have a fault-propagation fold associ- 

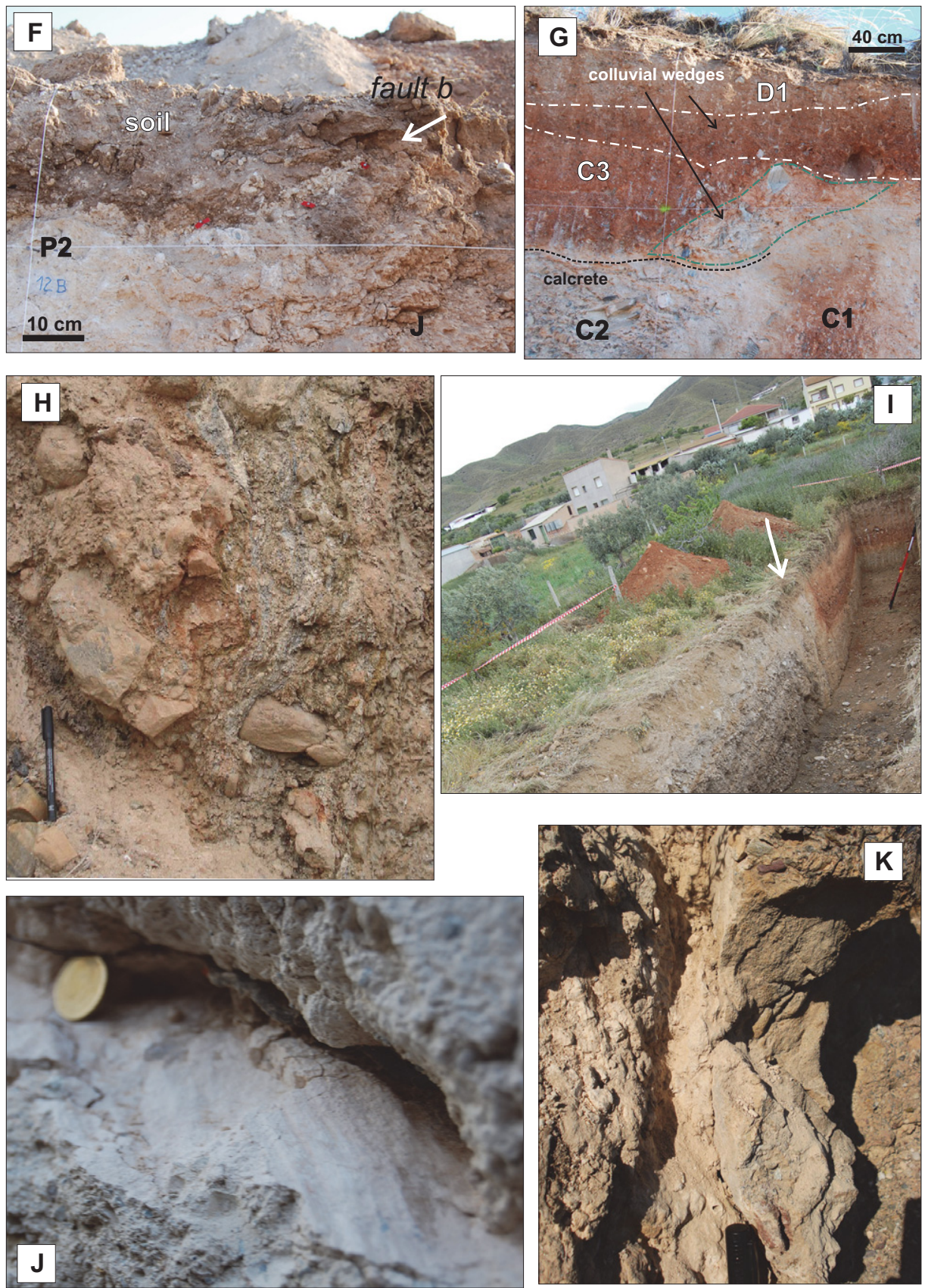

Figure 4 (continued). (F) Present-day soil rupture at the Tio Rey trench. (G) Colluvial wedges identified at the Carrascos-1 trench. (H) Góñar FS1 displacing Neogene conglomerates next to the Gabarrones site. (I) Era trench. (J) Fault plane with slickenlines at the Gabarrones trench. (K) Fault plane of the southern Alhama de Murcia fault at site 3. A pen is used for scale.

ated with each of them. The degree of folding is greater for the oldest units. Units D1 and D2 are gently folded. Only fault $\mathrm{a}^{\prime}$ displaces all the units. Adjacent to the faults, the clasts within the different beds are progressively rotated, and the beds of units B and $\mathrm{C} 1$ are stretched. Gouge is solely associated with fault a, which is less than $20 \mathrm{~cm}$ thick. Faults $\mathrm{a}^{\prime}$ and $\mathrm{b}$ match the axial by FS2, which dips $55^{\circ}$ to the $\mathrm{SE}$ and is continuous up to the present-day surface. The fault is associated with an asymmetric anticline (affecting unit B) in the upthrown block and a recumbent syncline (affecting units $\mathrm{C} 2$ and $\mathrm{C} 3$ ) in the downthrown block (Figs. 4 and 6C). The fault is characterized by a white fault gouge that is a few millimeters thick. Subhorizontal open fractures affect unit $\mathrm{C} 1$ next to the fault, indicating the existence of subhorizontal compressional stress orthogonal to the fault.

\section{Paleoseismic Events}

Five events were identified at Carrascos-1, Ca-1 to Ca-5 from youngest to oldest.

The youngest event, Ca-1, was associated with FS2. This event displaces the base of unit D2 (D2-1) but not the top (D2-2). The vertical displacement associated with this event is $23 \pm$ $11 \mathrm{~cm}$. The only age constraint of this event is the age of unit D1 at the Gabarrones trench, 21-25 ka TL, and the age of unit D3 at Era, 3.25-3.89 ka TL.

Event Ca-2 occurred on FS2 and FS3. Near FS2, the base of unit D1 and the previous units are more folded than the upper part of unit D1 and the subsequent units. The event occurred shortly after the deposition of the base of D1 and does not affect its upper part. At this fault, this event produced a vertical displacement of $36 \pm 4 \mathrm{~cm}$. At fault $\mathrm{b}$ (FS3), a deformation event led to the tilting of $\mathrm{C} 3$ and the underlying units, whereas D1 unit overlying fault b was not deformed. The horizon of this event next to fault b was placed below a colluvial unit interpreted as a tectonic colluvial wedge. Both events were considered as the same event $(\mathrm{Ca}-2)$ because the base of unit D1 (deformed by FS3 during this event) was probably not deposited next to FS2 or was removed by erosion after the earthquake. The accumulated vertical slip of these events at the base of D1 is $60 \pm 9 \mathrm{~cm}$. Thus, this event would be bracketed by units $\mathrm{C} 3$ and the middle part of D1. We selected the age of D1 at the Gabarrones site (21-25 ka TL at Gabarrones), and not the age of D2 at the Era site (12-16 ka pIRIR at Era) as the postdating age since the former is likely to be closer to the time of faulting than the latter. Summarizing, the age of event $\mathrm{Ca}-2$ can be constrained by C3 (46-60 ka pIRIR) and D1 (21-25 ka TL at Gabarrones).

Ca-3 is defined by a colluvial wedge formed next to fault $b$. This colluvial wedge is made of clasts derived from unit $\mathrm{C} 2$, which was probably uplifted and removed by erosion in the upthrown block. Additional evidence in support of Ca-3 is the intense red color (enhanced precipitation of ferrous minerals) at the base of unit C3 near the fault zone (Fig. 4G). This feature is interpreted as resulting from the formation of an 


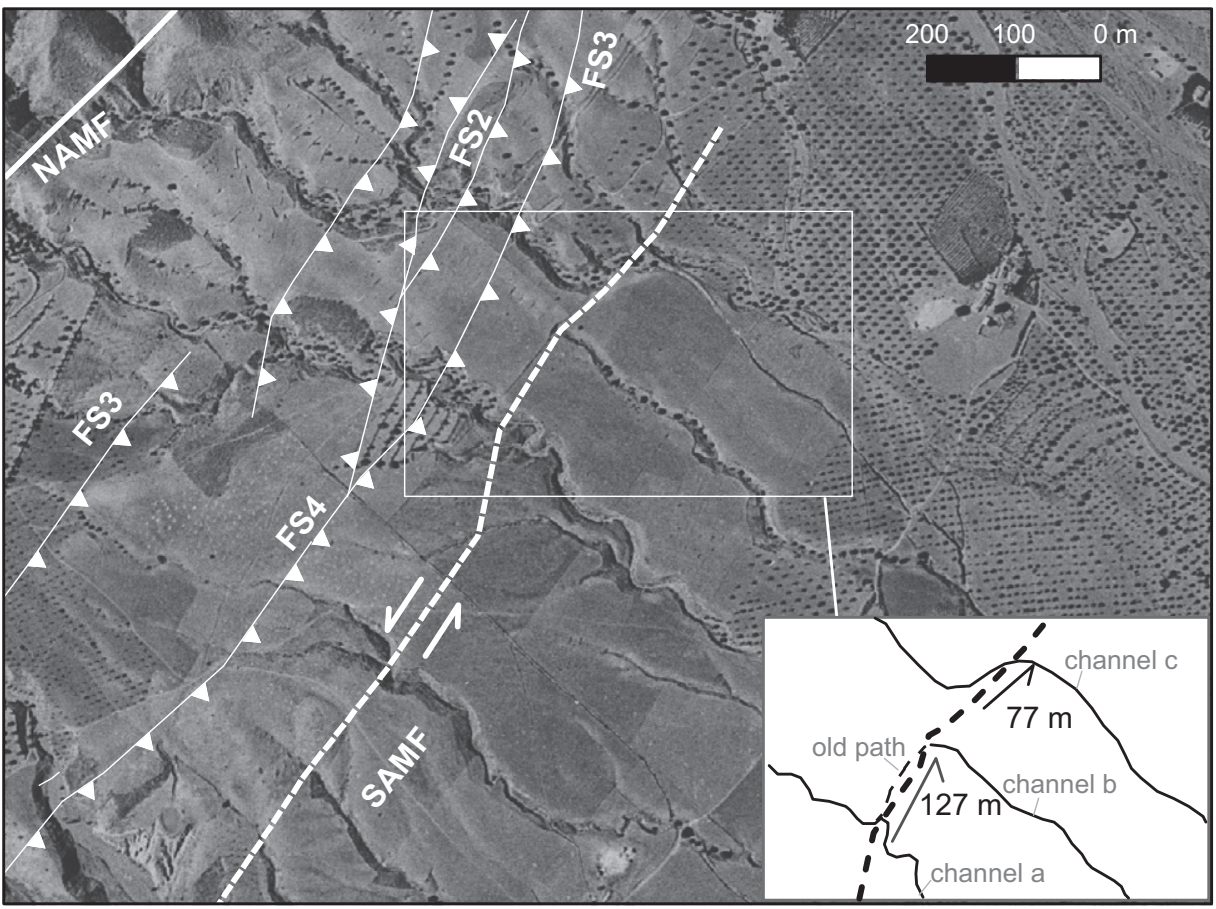

Figure 5. Orthophotograph obtained from the 1956 aerial photograph of the area (scale 1:30,000). The horizontal displacement of incipient gullies incised in alluvial-fan G4 is $127 \pm$ $6 \mathrm{~m}$ and $77 \pm 10 \mathrm{~m}$. The straightening of the main river channel has left an abandoned channel at the southernmost creek. The northernmost channel shows a twisted path with two $90^{\circ}$ turns. NAMF — northern Alhama de Murcia fault; FS—fault strand.

ephemeral pond at the toe of the scarp, possibly related to the obstruction of the drainage caused by the coseismic growth of the scarp.

The displacement associated with event $\mathrm{Ca}-3$ is $\sim 78 \pm 6 \mathrm{~cm}$. According to the relationships proposed by McCalpin (1996), the vertical displacement associated with one event is approximately twice the maximum thickness of the fault-derived colluvial wedge associated with it, in this case $39 \pm 3 \mathrm{~cm}$. Such a relationship is based on direct observations made on present-day fault ruptures (McCalpin, 1996) and is based on the fact that the coseismic colluvial wedges are made of clasts derived from the rapid degradation of the fault scarp after the earthquakes so that their maximum thickness (i.e., the thickness next to the fault) is approximately half of the original height of the scarp before its collapse.

Another estimation of the vertical slip can be obtained from the displacement of the base of unit $\mathrm{C} 3,27 \pm 5 \mathrm{~cm}$. These slip values are a minimum estimate of the total slip associated with such an event because it is an estimate of the vertical displacement and only corresponds to one of the fault strands of the system. This event occurred before the deposition of unit $\mathrm{C} 3$ (46-60 ka TL) and after a period of reduced sedimentation postdating unit C2 (103-26 ka TL).
This is corroborated by a calcrete layer on top of this unit and below the colluvial wedge.

The event horizon of $\mathrm{Ca}-4$ was located within subunit B2, the upper part of which was not affected by fault $\mathrm{a}^{\prime}$. Movement along fault $\mathrm{a}^{\prime}$ displaced fault a and the beds in subunit B1. Event $\mathrm{Ca}-5$ is indicated by faulting of subunit B1 and the basal part of B2. The envelope surface of the B1-B2 contact and of layers within B2 is displaced vertically by $117 \pm 8 \mathrm{~cm}$. Given that this displacement is likely to be the result of at least four events, a mean value of $23 \pm 2 \mathrm{~cm}$ per event is obtained. It was not possible to correlate the layers of unit B dated at Carrascos-2 and the layers of unit B exposed at Carrascos-1. The age of these two events can only be constrained as predating unit $\mathrm{C} 1$ (at the Era trench, 149-135 ka pIRIR) and postdating the unit before unit B, unit Q at Gabarrones (274-242 ka pIRIR).

Events from Ca- 1 to Ca- 5 cannot be well constrained by the deformation of the units exposed at Carrascos-2, where FS2 is exposed. Although the fault at this trench extends up to the presentday surface, no clear offset of the soil is observed. The propagation of the fault plane into the soil could be due to an event more recent than Ca-1. However, it could also be apparent and could result from an irregular development of the soil over the fault zone. Since such a hypothetical event is not observed at Carrascos-1, $80 \mathrm{~m}$ to the west, we did not interpret this feature as a real faulting of the soil. Consequently, all the events may have contributed to the formation of the drag fold observed at Carrascos-2, although they cannot be well constrained.

\section{Gabarrones Site (Strand 1)}

The Gabarrones geomorphological setting bears a strong resemblance to that of Carrascos-2. Here, the presence of a lighter-colored topographic high on G6 delimits the front of alluvial-fan G2 (Fig. 2). A trench was excavated perpendicular to this linear boundary between units G6 and G2, revealing the Góñar FS1. This fault strand is also exposed at the El Asno Creek with a $020-025 / 70^{\circ} \mathrm{SE}$ trend (slickenlines with $20^{\circ} \mathrm{S}$ pitch). It has an associated shear zone affecting a well-cemented conglomerate that is probably of middle Pleistocene age.

The deposits of alluvial-fan phases (Fig. 6D) are folded and faulted in such a way that (1) the beds of unit Q dip $\sim 70^{\circ} \mathrm{SE}$, (2) intermediate units $(\mathrm{B}, \mathrm{C} 1$, and $\mathrm{C} 2)$ are less folded and faulted, and (3) the youngest units are slightly deformed (C3) or undeformed (D1 and soil unit). The structure revealed at the trench corresponds to an asymmetric syncline with a faulted subvertical southeastern limb (Fig. 6D). All the faults in this limb merge at depth into a vertical fault (fault a) that represents the southeastern boundary of the fault zone. The overall structure is interpreted as a tilted push-up structure. This is supported by a lensoidal-shape defined by the faults in the NE wall of the trench. Fault b has an orientation of $087^{\circ} / 25^{\circ} \mathrm{S}$. The slickenlines on its plane have a pitch of $70^{\circ} \mathrm{W}$, indicating oblique reverse and left-lateral movement (Fig. 4J).

\section{Paleoseismic Events}

Evidence for five events, Ga- 1 to Ga-5 from youngest to oldest, was found at this site. The youngest event (Ga-1) tilted the synclinal structure to the NW, slightly folding unit $\mathrm{C} 3$. This is evidenced by the geometry of the internal layering of $\mathrm{C} 3$, which dips slightly to the SE and runs parallel to the contact between $\mathrm{C} 3$ and $\mathrm{C} 2$, except near the fault zone, where it dips to the NW. Since C3 is an alluvial unit with a NE provenance, the dip of its layers toward the NE is not expected to be a sedimentological feature. A minimum of $129 \pm 3 \mathrm{~cm}$ of vertical slip was inferred for this event by considering the offset of the base of $\mathrm{C} 3$, which is observed in the downthrown block and can be set to below the presentday soil in the upthrown block. Tilting is likely to be tectonic and cannot be ascribed to fault $b$, as unit $\mathrm{C} 3$ is not broken. The fault producing this tilting could either belong to the group of faults 

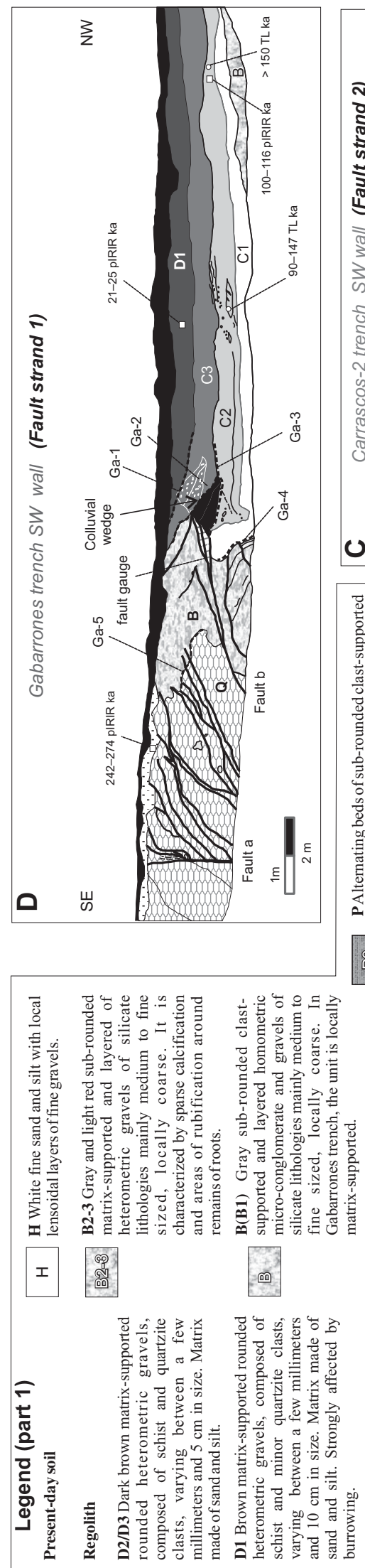
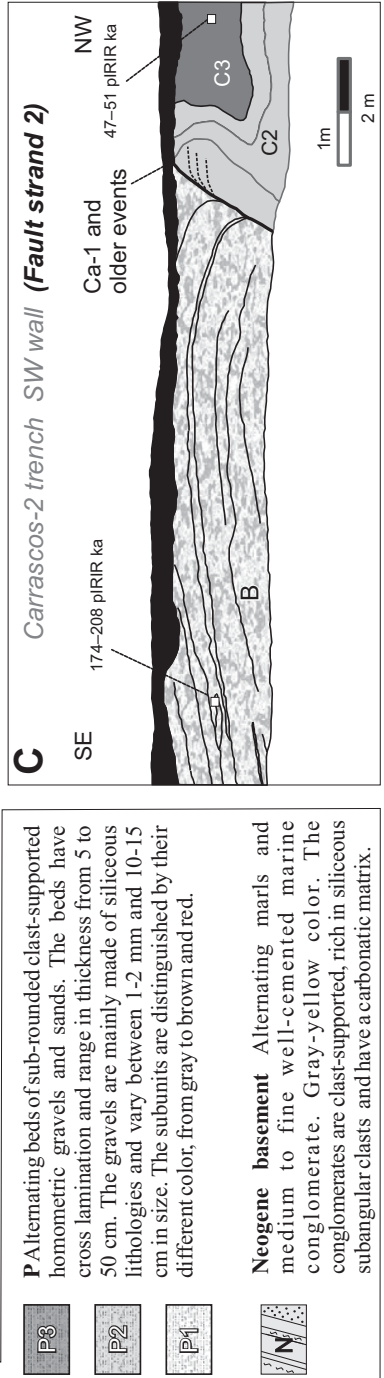

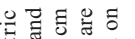

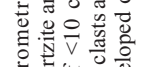

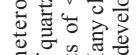

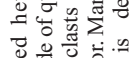

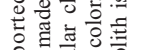

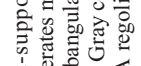

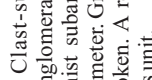

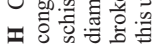

iㅏㅆㅏ.

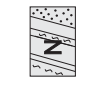

$\dot{x} \overline{0} \overrightarrow{0}$

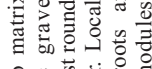
象. 蛋 을

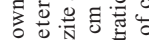

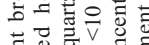

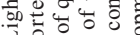
-
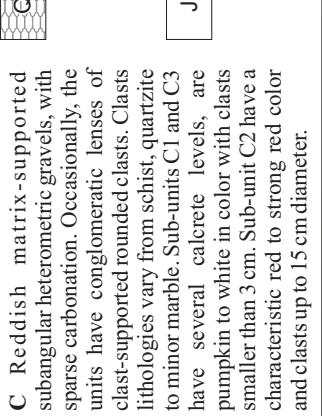

3

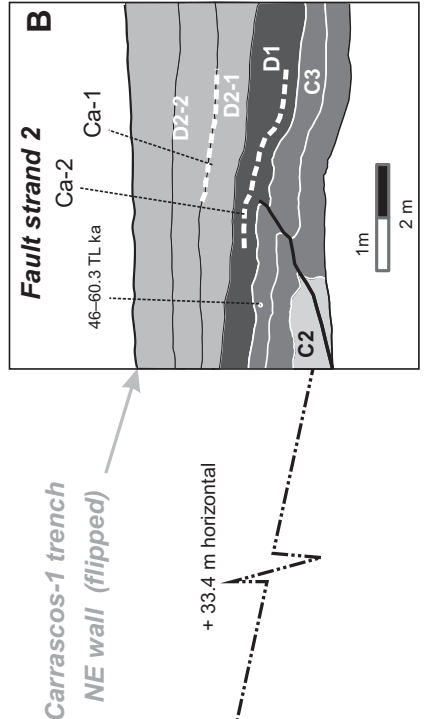

콩 


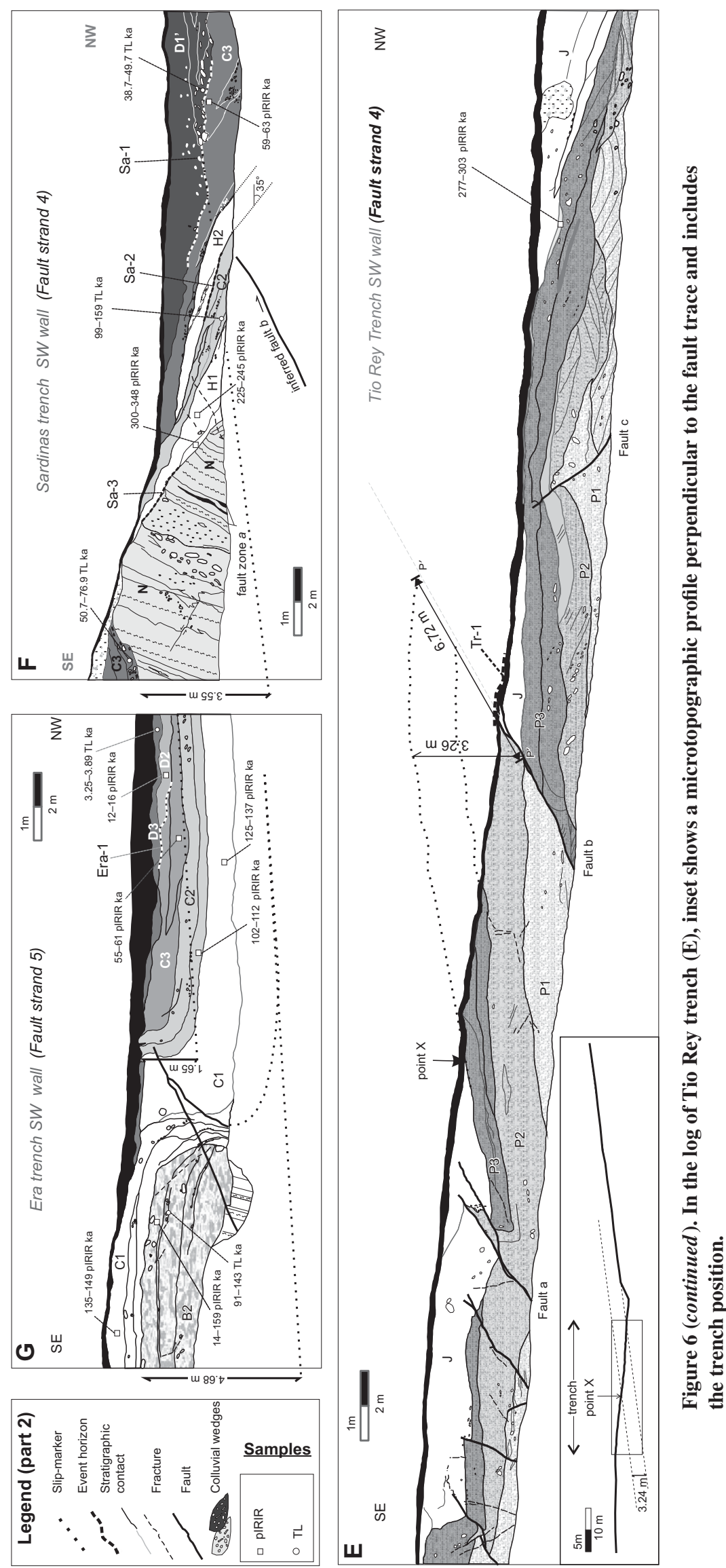

located to the SE or could be another fault not exposed at this trench and located more to the SE. This event occurred after the deposition of C3 (47-51 ka pIRIR at Carrascos-2) and before unit D1 (21-25 ka pIRIR).

The previous event, Ga-2, was caused by fault $\mathrm{b}$, which cut the colluvial wedge. The contact between the colluvial wedge and the overriding block is a fault. The uplifted part of the colluvial wedge was probably eroded away before the deposition of unit $\mathrm{C} 3$, which is expected, since the top of the fault scarp would be made of it.

The colluvial wedge consists of angular clasts derived from units $\mathrm{C} 1$ and $\mathrm{B}$ and was formed during an earlier event, Ga-3. Using the McCalpin (1996) estimates of displacement based on colluvial wedge thickness, we obtained a minimum vertical slip of $75 \mathrm{~cm}$ for event Ga-3. The Ga-2 and Ga-3 events occurred after the deposition of C2 (108-116 ka pIRIR ago) and before the deposition of C3 (47-51 ka pIRIR ago at Carrascos-2). The ages obtained at these trenches do not allow us to distinguish a different time constraint for these events.

The dip displacement of the Q-B contact along fault $\mathrm{b}$ is $103 \pm 22 \mathrm{~cm}$. This slip probably resulted from at least two events, one producing the colluvial wedge and a successive one displacing it. Then, $51 \pm 11 \mathrm{~cm}$ of dip displacement are attributed to each of the events Ga-2 and Ga-3. A $116 \pm 25 \mathrm{~cm}$ net slip per event was calculated using the aforementioned measure and the orientation of the slickenlines of the fault.

Events Ga-4 and Ga-5 are related to the movement along fault a and along the group of faults that merge into it. Event Ga-4 displaced unit B (174-208 ka pIRIR at Carrascos-2) but not unit C1 (100-116 ka pIRIR), so that an event horizon was placed at the base of unit $\mathrm{C} 1$. Event Ga-5 corresponds to the angular unconformity between units Q and B. Layers in unit Q dip steeply to the SE, with the result that more than one event probably occurred between their formation (before 258-274 ka pIRIR) and the deposition of unit B.

\section{Tio Rey Site (Branch 3)}

The Tio Rey site was chosen for excavation because of the antislope inflection of the alluvial-fan surface that favors sediment trapping. The precise location of the faults in the neighboring El Asno and Los Yesos Creeks helped to locate the trench (Fig. 2). The faults in the creek are oriented $060^{\circ} / 70^{\circ} \mathrm{SE}$ and have affected the Neogene marls and the overlying Quaternary alluvial fans.

The Tio Rey trench only exposes the deposits of alluvial phase G6 (units $\mathrm{P}$ and $\mathrm{J}$ in the trench log; Fig. 6). The units within the alluvial fan are 


\begin{tabular}{|c|c|c|c|c|c|}
\hline Event & Main evidence and slip and estimated value & Unit postdates/predates the event & $\begin{array}{l}\text { Age range } \\
\text { (ka) }\end{array}$ & Paleoearthquake & Fault branch \\
\hline Ga-5 & Faulting and folding (more than one event) & $\mathrm{B} / \mathrm{Q}$ & 174-208 (Carr-2), 242-274 & 6 & 1 \\
\hline Ca-5 & Faulting, $23 \pm 2 \mathrm{~cm}$ VS & $\mathrm{C} 1$ (top of $\mathrm{B}) /($ base of $\mathrm{B}) \mathrm{Q}$ & 135-149 (Era)/242-274 (Gaba) & 6 & 3 (fault a) \\
\hline $\mathrm{Ga}-4$ & Faulting & $\mathrm{C} 1 / \mathrm{B}$ & 100-116/174-208 (Carr-2) & 5 & 1 \\
\hline $\mathrm{Ca}-4$ & Faulting, $\sim 20 \mathrm{~cm}$ & $\mathrm{C} 1 / \mathrm{Q}$ & $135-149$ (Era), 242-274 (Gaba) & 5 & 3 (fault a) \\
\hline Sa-3 & Change in sedimentary conditions & $\mathrm{C} 2$ (base of $\mathrm{H} 1$ )/Neogene & $>99-159$ & 4,5 , and/or 6 & 4 \\
\hline Ga-3 & Colluvial wedge, $75 \mathrm{~cm}$ VS & $\mathrm{C} 3 / \mathrm{C} 2$ & 47-51 (Carr-2)/108-116 & 4 & 1 \\
\hline Sa-2 & Change in sedimentary conditions & $\mathrm{C} 3 / \mathrm{C} 2$ & $59-63 / 99-159$ & 3 and/or 4 & 4 \\
\hline $\mathrm{Ca}-3$ & $\begin{array}{l}\text { Colluvial wedge, change in sedimentary conditions. VS } \\
\text { between } 78 \pm 6 \mathrm{~cm}\end{array}$ & Contact $\mathrm{C} 3 / \mathrm{C} 2$ & $46-60 / 103-126$ & 3 or 4 & 3 (fault b) \\
\hline Ga-2 & Faulting, $51 \pm 11 \mathrm{~cm} \mathrm{VS,} 116 \pm 25 \mathrm{~cm} \mathrm{NS}$ & $\mathrm{C} 3 / \mathrm{C} 2$ & 47-51 (Carr-2)/108-116 & 3 & 1 \\
\hline Ga-1 & Angular unconformity, $129 \pm 3 \mathrm{~cm}$ VS & D1/C3 & $21-25 / 47-51$ (Carr-2) & 2 & 1 \\
\hline Sa-1 & Angular unconformity, $3.55 \mathrm{~m}$ VS (more than one event) & $\mathrm{D} 1 / \mathrm{C} 3$ & $39-50 / 59-63$ & 2 or 3 & 4 \\
\hline Ca-2 & $\begin{array}{l}\text { Colluvial wedge, angular unconformity } \\
36 \pm 4 \mathrm{~cm} \text { (FS3) VS of base of D1 }\end{array}$ & Within D1 ( D2/C3) & $21-25($ Gaba)/46-60 & 2 & 2 and 3 \\
\hline $\mathrm{Ca}-1$ & Angular unconformity , $23 \pm 11 \mathrm{~cm}$ VS of D2-1/D2-1 & Within D2 (D1/D3) & 3-4 (Era)/21-25 (Gaba) & 1 & 2 \\
\hline Era-1 & Angular unconformity & $\mathrm{D} 2 / \mathrm{C} 3$ & $3-4 /(12-16) 51-61$ & 1 & 5 \\
\hline Tr-1 & Present-day soil rupture, $<15 \mathrm{~cm}$ DS & Present-day soil/J & Holocene & 1 & 4 \\
\hline
\end{tabular}

part of a train of synforms and antiforms affecting units $\mathrm{P}$ and $\mathrm{J}$. In most of the trench, the layers do not show their natural slope but are tilted toward the NW, i.e., facing uphill. These folds have been cut by a series of reverse faults, most of them dipping SE (e.g.: a, oriented $058^{\circ} / 35^{\circ} \mathrm{SE}$; $\mathrm{b}$, oriented $060^{\circ} / 35^{\circ} \mathrm{SE}$ ) and one dipping NW (fault c, oriented $030^{\circ} / 45^{\circ} \mathrm{NW}$ ). Fault b has slickenlines with a pitch of $80^{\circ} \mathrm{W}$, indicating a reverse left-lateral component. The faults have discrete fault gouges consisting of well-cemented white silt. All the faults exposed at the trench are probably secondary faults associated with the main faults observed at the El Asno Creek.

We calculated the long-term net slip accommodated by the exposed faults. To this end, we undertook a microtopographic profile of the folded surface of alluvial-fan G6. The profile was perpendicular to the trace of FS4 and contained the trench (inset of Fig. 6E). The base of unit $\mathrm{J}$ near the reference point $\mathrm{X}$ dips $7^{\circ}$ to the $\mathrm{SE}$, as in the microtopographic profile in the NW sector. By extrapolating the present-day surface of G6 to the trench, we obtained a minimum vertical displacement of $3.24 \pm 0.36 \mathrm{~m}$ of unit J. This value is equivalent to the vertical displacement of $3.26 \pm 0.36 \mathrm{~m}$ of this unit associated with fault $b$, which corresponds to a dip slip of $6.72 \pm 0.74 \mathrm{~m}$ (Fig. 6D).

\section{Paleoseismic Events}

We were only able to constrain one event at the Tio Rey trench, event Tr- 1 . The movement along fault $\mathrm{b}$ has a major vertical component, as inferred from the slickenlines and from the vertical offset of the units. This fault extends toward the surface and displaces the top soil unit by $\sim 15 \mathrm{~cm}$ along the dip (Fig. 4F). Thus, an event horizon was placed at the top of the soil unit $(\operatorname{Tr}-1)$. The age of this event is uncertain. Given that the area is affected by natural erosion and by plowing, it is debatable whether the soil affected by the fault is a modern one. A tentative Holocene age has been assigned to event $\mathrm{Tr}-1$ in accordance with the degree of soil development.

A total offset of $6.72 \pm 0.74 \mathrm{~m}$ along the dip on this fault suggests the occurrence of some earlier earthquakes, identified as Tr-X, after the deposition of unit P, i.e., after $290 \pm 13$ ka pIRIR.

\section{Sardinas Site (Branch 4)}

The Sardinas trench is located at Góñar (Figs. 2 and $6 \mathrm{~F}$ ), on the trace of FS4. The site corresponds to an asymmetric hill, with a maximum height of $\sim 3 \mathrm{~m}$ on the steepest, NW-facing side. The exposure at this trench showed that the Neogene basement is uplifted, blocking alluvial fans G3 and G2 sourced from the Las Estancias range. During the deposition of G3, the alluvial fan overran the scarp, as indicated by the preservation of the G3 alluvial deposits (unit C3) at the top of the hill (Fig. 6F).

The Neogene sequence at this site consists of an alternation of conglomeratic beds (with rounded clasts) and marls dipping $80^{\circ} \mathrm{SE}$. Units $\mathrm{H}$ to $\mathrm{C} 3$ dip to the NW, and unconformably overlie the basement. Units $\mathrm{H} 1$ and $\mathrm{H} 2$ consist of clasts embedded in a pale silty matrix. The color and lithology of units $\mathrm{H} 1$ and $\mathrm{H} 2$ indicate that they are derived from the Neogene basement exposed in the upper part of the trench. Units H1 and $\mathrm{H} 2$ are interpreted as colluvial units generated by the degradation of the Sardinas scarp. Clast imbrications and lithology of alluvial units $\mathrm{C} 2, \mathrm{C} 3$, and D1 confirm that sedimentary load comes from the Las Estancias range.

FS4 consists of at least two fault strands, fault a and "inferred fault b." The Neogene sequence is affected by a 40-50-cm-thick fault zone, i.e., fault a, which is oriented $045^{\circ} / 75^{\circ} \mathrm{SE}$ and is parallel to the bedding. The fault gouge is characterized by c-s structures, indicating a dominant reverse movement with a minor leftlateral component. Deformation along fault a could have contributed to the progressive uplift of the Sardinas hill in the past, but it did not affect the overlying deposits (unit $\mathrm{H}$ and soil). Its location and orientation do not account for the folding of the overlying units (H1 to $\mathrm{C} 3$ ), which must have been generated by movement along an inferred fault, fault $b$. Deformation of the layers in the footwall of fault a is expressed as an open fold with the axial plane dipping to the SE and probably coincident with the inferred fault b. Strong tilting of the layers to the NW is observed. The $10^{\circ}$ dip in the central part of the trench increases to $35^{\circ}$ in the northwestern part. The uppermost unit, D1, is the only nondeformed unit. The $6^{\circ}$ dip of the layers to the SE is probably depositional, since it is coincident with the general slope of alluvial-fan G2 obtained through microtopography. The top of this unit has been transformed by plowing.

\section{Paleoseismic Events}

Evidence of at least three paleoearthquakes was obtained at this site, $\mathrm{Sa}-1$ to $\mathrm{Sa}-3$ from youngest to oldest. The youngest event observed, Sa-1, is defined by an angular unconformity located at the base of unit D1'. This event also caused the uplift of part of unit C3 located at the top of the hill. To estimate the minimum vertical offset associated with this event, we assumed that the original surface of alluvial-fan G3 had the same slope as the surface of the undeformed alluvial fan $\mathrm{G} 2$, i.e., $6^{\circ}$ to the SE. Then, we restored the folding affecting unit C3 (alluvial-fan G3) in the northwestern block and projected its base underneath unit $\mathrm{C} 3$ in the southeastern block (Fig. 6F). This projection suggests a minimum vertical displacement of $3.55 \pm 0.39 \mathrm{~m}$ for the base of $\mathrm{C} 3$. The age of this 
event is constrained by unit D1' (39-50 ka TL) and unit C3 (59-63 ka pIRIR). Event Sa-1 probably corresponds to several events, as suggested by the anomalously large throw of $3.55 \mathrm{~m}$ associated with it.

The identification of events Sa-2 and Sa- 3 is based on the change in sedimentary environment represented by the base of units $\mathrm{H} 1$ and $\mathrm{H} 2$, respectively. In each of these earthquakes, the Sardinas hill would have been uplifted, and the newly exposed basement rock would have been rapidly eroded and deposited at the foot of the scarp. The high erodibility of the basement rocks suggests that the colluvial layers ( $\mathrm{H} 1$ and $\mathrm{H} 2$ ) were formed in a relatively short period after two events. Alluvial sediments (C2) were deposited between this rapid sedimentation associated with $\mathrm{H} 1$ and $\mathrm{H} 2$. Thus, event $\mathrm{Sa}-2$ should have occurred between units $\mathrm{C} 2$ and $\mathrm{C} 3$, i.e., between $59 \mathrm{ka}$ and $159 \mathrm{ka}$ TL. Event Sa-3 occurred before the deposition of C2 (99-159 ka TL), so that a $99 \mathrm{ka}$ TL age is considered as a minimum age for it.

We did not consider the ages obtained for the $\mathrm{H} 1$ colluvial deposit since the distance from the source was insufficient to ensure the total bleaching of the grains used for the luminescence dating.

\section{Era Site (Branch 4)}

The Era site is located at Góñar, next to the head of a highly entrenched active creek that provides a good exposure of the fault (site 6 in Figs. 2A and 4E). At the surface, this site shows a gentle step of $\sim 1 \mathrm{~m}$, separating orchards (in the downthrown block) from an abandoned threshing floor (in the upthrown block). In the northwestern margin of the creek, the Góñar FS4 can be deduced from the sharp contact between vertical Neogene marl in the hanging block and late Quaternary alluvial deposits in the downthrown block. Another natural exposure of this fault can be observed at site 1 (Fig. 2), where the layers of alluvial-fan G3 are folded and thrusted $0.5 \mathrm{~m}$ to the NW. The fault is oriented $055^{\circ} / 50^{\circ} \mathrm{SE}$ in the natural outcrop and $060^{\circ} / 25^{\circ} \mathrm{SE}$ at the trench.

Two faults are observed along the axial planes of the folds affecting the units in the Era trench (Fig. 6G). Alluvial-fan G5 (unit B2) is overlain by alluvial-fan G3 (unit C1), both being folded and thrusted toward the N-NW over alluvialfans G3 (unit C1-3) and G2 (units D2 and D3). This deformation caused an antiformal fold in the overthrusting block and a synformal fold in the downthrown block. The faults exposed are more easily identified in the units with a wellcemented matrix (the upper part of $\mathrm{C} 1$ and $\mathrm{C} 2$ ), where discrete fault planes can be observed. However, in the units that are clast supported, the fault can only be inferred from the alignment of the clasts. Small offsets of $\sim 10 \mathrm{~cm}$ were observed within unit $\mathrm{C} 1$ and at the $\mathrm{C} 1-\mathrm{C} 2$ contact. The overall structure bears a strong resemblance to that exposed at the Carrascos- 1 and Carrascos-2 trenches (Fig. 6A). A vertical displacement of $4.68 \mathrm{~m}$ associated with this fault was estimated by considering the $\mathrm{C} 1-\mathrm{B}$ contact in the upthrown block and its estimated depth at the downthrown block. The contact was drawn taking into account the maximum thickness of C1 observed underneath the fault (Fig. 6G). This is a minimum estimate of the vertical slip since the base of unit $\mathrm{C} 1$ is probably located at a lower position.

\section{Paleoseismic Events}

At this trench, it was possible to constrain only one event, Era-1, at the top of unit C3. Unit C3 is folded, in contrast to unit D3, suggesting that the event occurred after $\mathrm{C} 3$ (at this trench, 55-61 ka pIRIR) and before the deposition of unit D3 (3.25-3.89 ka TL). Since it was not possible to ascertain whether D2 was deformed, it is debatable whether this event occurred before the deposition of unit D2. However, the fact that D2 was not preserved on the hanging block suggests that unit D2 was uplifted during event Era-1 and was subsequently eroded away. We used the age of $\mathrm{C} 3$ as the maximum age for this event, although it should be borne in mind that this event could be younger than D2. The top of $\mathrm{C} 3$ is therefore considered to be the paleosurface after this event (Fig. 6G).

\section{DISCUSSION}

In this section, the timing of the events obtained for the six paleoseismologic trenches is compared to obtain the correlation of the events, i.e., the common event chronologies that could account for the deformation at the different sites. The slip rates derived from the trench analysis are also discussed. The results are compared with the event chronologies and slip rates of the neighboring paleoseismological sites studied by other authors. This comparison allows us to evaluate the maximum fault rupture inferred from the correlation of the events, and to provide some estimates of the maximum magnitude expected in the region. Finally, some geodynamical implications are discussed at the end of the section.

\section{Correlation among the Paleoseismic Events at the Goñar Faults}

We used the term "paleoearthquake" for the paleoseismic events derived from the correlation between different trenches, while the term "events" is restricted to those identified by a single trench analysis (e.g., Ca-1, etc.). The summary of the age constraints and slips associated with all the events is provided in Table 3 . The correspondence between each event and the common paleoearthquake is given in this table. The paleoearthquakes are listed as 1-6, from youngest to oldest.

At minimum, six paleoearthquakes are inferred. This is a minimum estimate of the paleoearthquakes recorded at the trenches, since we cannot be sure that all the earthquakes were recorded. In the oldest units, the deformation attributed to a single event is possibly the result of two or more successive events. In the case of folds, it is not easy to interpret the deformation in terms of the number of events. The same thing occurs when assessing the number of events related to a large displacement, such as the one observed at the Tio Rey trench. Figure $7 \mathrm{~A}$ is a synthesis of the event chronologies, where the time uncertainty (time span) of each event is represented along the $x$ axis.

In order to assess a minimum number of paleoearthquakes derived from the correlation between the different trenches, we first compared the two trenches recording a maximum number of events, i.e., the Carrascos and Gabarrones trenches. These trenches are located at $\sim 500 \mathrm{~m}$ from each other, so that correlation between the units exposed is easier than between more distant trenches. The correlation of events recorded at these two trenches enables us to infer a minimum of six paleoearthquakes: (1) paleoearthquake 1 corresponds to event $\mathrm{Ca}-1$, which is not recorded at the Gabarrones trench; (2) paleoearthquake 2 is event $\mathrm{Ca}-2$, which matches Ga-1; (3) paleoearthquakes 3 and 4 are represented at Gabarrones by Ga-2 and Ga-3, respectively, and one of these events matches $\mathrm{Ca}-3$ at the Carrascos trench; (4) paleoearthquake 5 corresponds to events $\mathrm{Ca}-4$ and $\mathrm{Ga}-4$; and (5) paleoearthquake 6 corresponds to events $\mathrm{Ca}-5$ and $\mathrm{Ga}-5$.

By correlating the time distribution of these six paleoearthquakes with that of the events at the other trenches, it is possible to refine the age constraints of the paleoearthquakes. Some events can be correlated in a unique mode. However, others might correspond to several of the paleoearthquakes identified at Carrascos and Gabarrones. Analysis of the possible combinations of events allows us to consider three chronologies (known as options 1-3) that are compatible with the event timing determined in this work (Fig. 7A). The time constraint resulting from each specific combination of events is specified in brackets next to each paleoearthquake.

In the three options, paleoearthquakes 1, 5, and 6 are defined in the same way; paleoearth- 
Figure 7. (A) Age constraint of the paleoearthquakes (PE) in the Góñar area. The bracketing units are included. In the age axis, the rhombus symbols represent a recurrence of $25 \mathrm{k.y}$. (black) and $20 \mathrm{k.y}$. (gray). (B) Synthesis of the events observed in the Gónar area and those deduced in the LorcaTotana segment of the Alhama de Murcia fault and in the Albox fault. NAMF-northern Alhama de Murcia fault; SAMFsouthern Alhama de Murcia fault.

quake $1(3-25 \mathrm{ka})$ is defined by events $\mathrm{Ca}-1$ and Tr-1, paleoearthquake 5 (135-208 ka) is defined by events $\mathrm{Ca}-4$ and $\mathrm{Ga}-4$, and paleoearthquake 6 (174-274 ka) is defined by events $\mathrm{Ca}-5$ and Ga-5. Era-1 matches paleoearthquake 1 but also paleoearthquake 2 in all of the options, but this does not change the time range of the paleoearthquakes. The same thing happens with $\mathrm{Ca}-3$, which matches paleoearthquake 3 and paleoearthquake 4 , and with $\mathrm{Sa}-3$, which could represent paleoearthquake 4,5 , or 6 . The multiple event $\mathrm{Tr}-\mathrm{X}$ could include all six paleoearthquakes.

The three paleoearthquake chronologies result from a different combination of events in paleoearthquakes $2-4$, and are defined as follows: (Option 1) In this option, paleoearthquake $2(21-51 \mathrm{ka})$ is defined by $\mathrm{Ca}-2$ and Ga-1, paleoearthquake 3 (47-63 ka) is defined by events $\mathrm{Ga}-2$ and Sa-1, and paleoearthquake 4 (59-116 ka) is represented by events Ga-3 and Sa-2. (Option 2) In this option, paleoearthquake 2 (39-51 ka) is defined by Ca-2, Ga-1, and Sa-1, paleoearthquake $3(59-116 \mathrm{ka})$ is defined by events $\mathrm{Ga}-2$ and $\mathrm{Sa}-2$, and paleoearthquake 4 (99 and $116 \mathrm{ka}$ ) is represented by events Ga-3 and Sa-3. (Option 3) In this option, paleoearthquake $2(39-51 \mathrm{ka})$ is represented by $\mathrm{Ca}-2$, Ga-1, and Sa-1, paleoearthquake 3 (46-116 ka) is only defined by event $\mathrm{Ga}-2$, and paleoearthquake 4 (59 and $116 \mathrm{ka}$ ) is defined by events Ga-3 and $\mathrm{Sa}-2$.

Of the three options, option 2 is the one that yields a finer age constraint for paleoearthquakes 2 and 4 . This is because in this option, compatible events of a very different age range are being correlated, so that the common time interval between them is shorter than in the other options.

Apart from these paleoearthquakes, a more recent paleoearthquake could have been recorded at the Tio Rey and Carrascos- 2 trenches, where an apparent rupture of the soil was observed. The interpretation of these ruptures as a very recent rupture, younger than $3 \mathrm{ka}$ (minimum age constraint of paleoearthquake 1 ), is

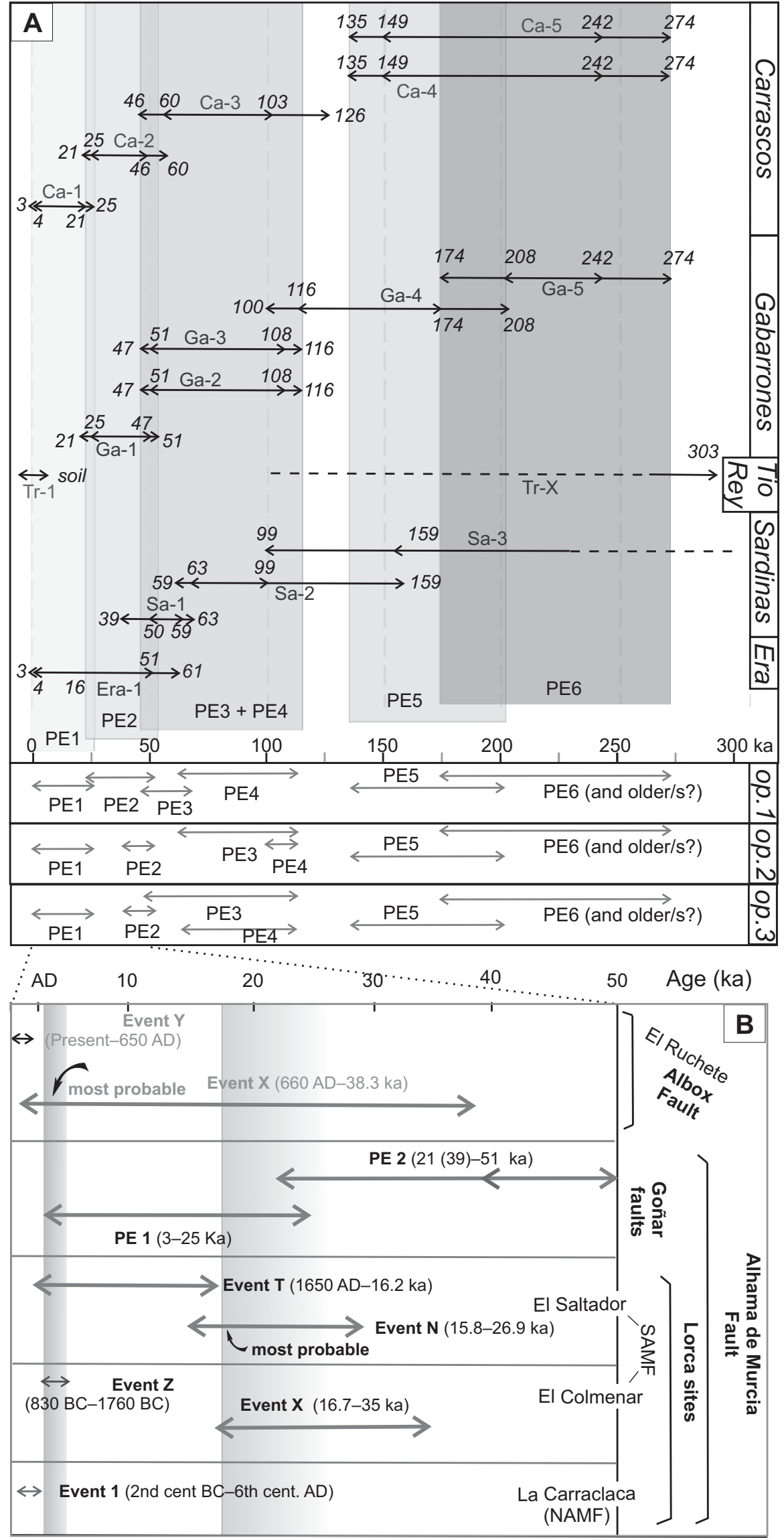


not straightforward, and this should be borne in mind in future research. As mentioned in the previous section, the apparent offset of the soil unit could be the result of an adaptation of the soil to the fault zone, which is harder than the surrounding material at both trenches. Moreover, the displacement could be real, but the soil could be an exhumed soil affected by pedogenetic processes.

In the case of very recent ruptures, the absence of an associated surface scarp could be attributed to two factors: (1) the enhanced erosion affecting the surface and/or (2) the obliteration of the slip by natural erosion or agricultural transformation of the land.

\section{Seismogenic Segmentation of the Goñar Fault Strands}

The comparison of the event chronologies of the different trenches helped us to better understand the seismogenic behavior of the system during an earthquake.

The event chronologies suggest that seismogenic ruptures are able to propagate along all the length of the fault splay, as evidenced by a similar number of events recorded at the opposite trenches, i.e., Carrascos-1 and Sardinas (Figs. 6 and 7A).

However, a comparison of the frontal and the inner fault strands shows some differences. The northwesternmost strands (FS1-Gabarrones and FS4-Sardinas) do not seem to have been active during the last two paleoearthquakes (paleoearthquake 1 and the recent earthquake possibly recorded at Tio Rey and Carrascos-2). Conversely, the remaining paleoearthquakes seem to have been recorded at all the fault strands of the Góñar system, which suggests that all the strands could move simultaneously. FS1 and FS4 are aligned and could be part of a single fault trace. Since such a fault trace is located in the hinterland of the system, the cessation of its activity during the most recent paleoearthquakes can be interpreted as the result of a transfer of the activity to the SE in a piggyback manner. Further evidence is warranted for a detailed discussion of this subject.

\section{Correlation of the Event Chronologies with Neighboring Paleoseismologic Sites}

The linkage between the Alhama de Murcia fault and the Albox fault has been discussed in earlier studies (e.g., Masana et al., 2005; Pedrera et al., 2010), as has the seismogenic segmentation of the Alhama de Murcia fault (Martínez-Díaz, 1998; Martínez-Díaz et al., 2001, 2003; Masana et al., 2004, 2005; Silva et al., 1997, 2003).

The chronology of paleoearthquakes obtained in this work can be compared with that obtained in earlier studies in the area. Since these studies concern trenches with only young units (in contrast to the Góñar trenches), only the chronology of paleoearthquakes 1 and 2 can be compared.

\section{Góñar and Lorca Sites}

A comparison of the event chronologies of the trenches at the Gónar fault system with those at the southern Alhama de Murcia fault at Lorca (Fig. 7B) yields the following scenarios: (Scenario 1) Two fault zones "simultaneously" rupture during paleoearthquake 1 and paleoearthquake 2. (Scenario 2) The fault ruptures are different in one of the paleoearthquakes but are the same in the other. (Scenario 3) None of the paleoearthquakes corresponds with events at the Lorca sites. In scenario 1, the "simultaneous" rupture could be due to a single event or to two independent events during which one of the fault segments triggered the slip in the other segment. It is not possible to differentiate the single rupture from the triggered rupture by using the available time constraints, since a triggering behavior means that such successive events could be separated by minutes or hours.

If it were assumed that the simultaneous rupture of the entire Lorca-Góñar system took place (scenarios 1 and 2), the age range of the events at Gónar would be narrowed because the timing of the events at the Lorca sites (reported in Martínez-Díaz et al., 2003; Masana et al., 2004) is better constrained. The proximity between the El Colmenar and El Saltador sites (Fig. 1B) allows us to assume the synchronicity of their events (only two paleoearthquakes are identified). The youngest one would be constrained by events $\mathrm{T}$ (El Saltador) and Z (El Colmenar), henceforth event TZ, so that it would have occurred between 830 B.C. and 1750 B.C. (this is 2.8 and $3.8 \mathrm{ka}$ ). The oldest one, represented by event X (El Colmenar) and event N (El Saltador), henceforth event XN, would have occurred between 16.7 and $26.9 \mathrm{ka}$, but probably immediately before $16.7 \mathrm{ka}$ (for discussions of these time brackets, see Masana et al., 2004).

For scenario 1 (simultaneous rupture of the two fault zones during paleoearthquake 1 and paleoearthquake 2), paleoearthquake 1 in the Góñar faults would correspond to event TZ, while paleoearthquake 2 would match event XN. Then, paleoearthquake 1 would have occurred between 3 and $3.8 \mathrm{ka}$, and paleoearthquake 2 would have occurred between 21 and 26.9 ka. Paleoearthquake 2 is only compatible with event $\mathrm{XN}$ if the wider time range of the two last events is considered (and not the most probable age immediately before $16.7 \mathrm{ka}$ ). This scenario is not compatible with options b and c of the Góñar chronologies, since paleoearthquake 2 has a minimum age of $39 \mathrm{ka}$ in these options (Fig. 7A).
For scenario 2 (the fault ruptures are different in one of the paleoearthquakes but are the same in the other), three combinations are possible. First, paleoearthquake 2 only matches the oldest events at Lorca with the age constraints as in scenario 1, but without correlation of paleoearthquake 1 and event TZ. Paleoearthquake 2 cannot be correlated with event TZ but only with event $\mathrm{XN}$. The two other correlations consider that paleoearthquake 2 was not simultaneous with events at Lorca, but that only paleoearthquake 1 can be correlated with either the youngest or the oldest event. If paleoearthquake 1 correlates with the oldest event $(\mathrm{XN})$, then its time constraint would be coincident with the time brackets of event $\mathrm{XN}, 16.7$ and $26.9 \mathrm{ka}$. This range could be narrowed if the most probable age (immediately before $16.7 \mathrm{ka}$ ) is considered. If paleoearthquake 1 is correlated with the youngest event (TZ), then the chronology is as stated for scenario 1 but with no correlation between paleoearthquake 2 and the events at Lorca.

Scenarios 1 and 2 entail a fault rupture greater than $40 \mathrm{~km}$ (Fig. 1B), which has major implications for the seismic hazard of the region.

\section{Góñar and Albox Sites}

The ages of event $\mathrm{X}$ at the Albox fault are compatible with paleoearthquake 1 and paleoearthquake 2 at the Góñar trenches (Fig. 7B). If it were synchronous with paleoearthquake 1 , such an event would have occurred between 3 and $25 \mathrm{ka}$, whereas if it were synchronous with paleoearthquake 2 , the time constraint would be between 21 and $38.3 \mathrm{ka}$. The youngest event recorded at the Albox fault (event $\mathrm{Y}$ ) is a recent event that apparently occurred during historical times, though it is not identified in the historical catalog. This event is not identified at any of the other faults (Fig. 7B).

These faults can move as reverse faults under a compressive regime oriented N-NW. A continuous coseismic rupture at the Albox and the Góñar faults is difficult to envisage because of the absence of a clear fault trace between them.

\section{Slip Rate across the Alhama de Murcia Fault-Góñar Fault System}

\section{Individual Slip Rates}

The vertical slip rates obtained for individual strands range between 0.01 and $0.08 \mathrm{~mm} / \mathrm{yr}$ (Table 4). For the Era trench (FS5), it was possible to obtain the vertical slip for three horizons: the base of units $\mathrm{C} 1, \mathrm{C} 2$, and $\mathrm{C} 3$. To this end, the logged fold geometry was completed in the upthrown block (for C2 and C3) and the downthrown block (for $\mathrm{C} 1$, see Fig. 6G). The slip rate using the base of $\mathrm{C} 1(0.02-0.04 \mathrm{~mm} / \mathrm{yr})$ is in agreement with the one obtained for $\mathrm{C} 3$, 
TABLE 4. SLIP RATES DERIVED FROM THE TRENCH ANALYSIS

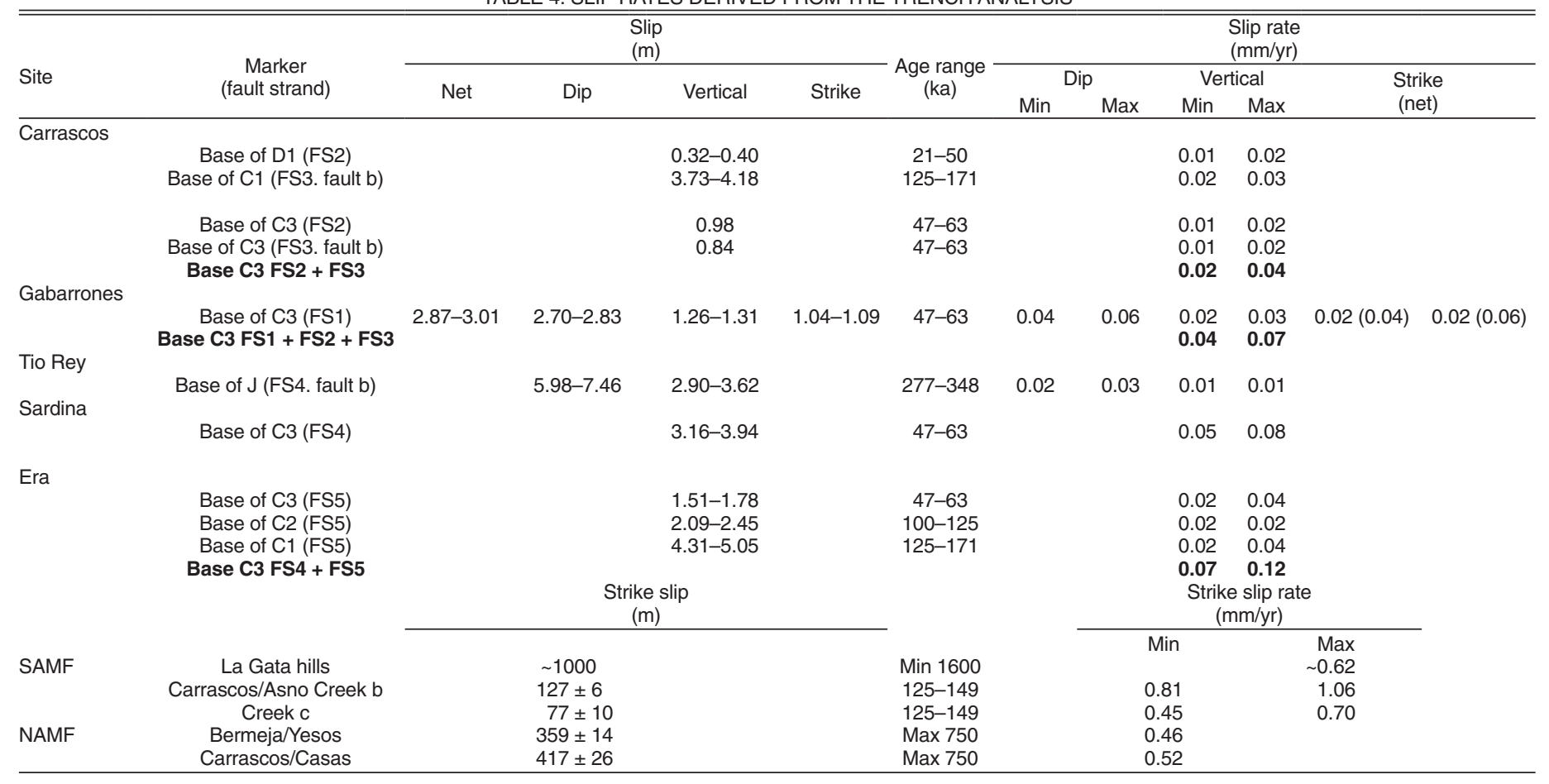

whereas the slip rate derived for the base of $\mathrm{C} 2$ $(\sim 0.02 \mathrm{~mm} / \mathrm{yr})$ is similar or smaller. This difference could be due to a slowing down of the slip rate during the deposition of $\mathrm{C} 2$ or to a decrease in the average sedimentation rate. It should be noted that the fast floods generating units $\mathrm{C} 1-$ C3 led to a discontinuous sedimentation rate, with the result that variations in the slip rates are expected.

The strike-slip rates of the northern Alhama de Murcia fault and the southern Alhama de Murcia fault were estimated between 0.45 and $1.33 \mathrm{~mm} / \mathrm{yr}$, respectively. The average of the minimum strike slip for these faults is 0.51 $\mathrm{mm} / \mathrm{yr}$ (Table 4).

For the northern Alhama de Murcia fault, the strike-slip rate was obtained by using the deflections of Bermeja/Yesos and Carrascos/ Casas Creeks (see section on the southern tip of the Alhama de Murcia fault) and a maximum age of $750 \mathrm{ka}$ (end of the middle Pleistocene), which was considered to be the most suitable estimate for the emplacement of the present-day drainage.

For the southern Alhama de Murcia fault, the strike-slip rate was calculated using (1) the deflections of channels a and $\mathrm{b}$ incised in alluvial-fan G4 (between Carrascos and El Asno Creeks), bearing in mind that the oldest age for the "undeflected" channel is the age of the alluvial fan, 125-149 ka (Figs. 2 and 5; Table 2) and (2) the $\sim 1 \mathrm{~km}$ left-lateral fault displacement of the Pliocene-Quaternary strata of La Gata Hills (see section on the southern tip of the Alhama de Murcia fault), for which 1.6 Ma is considered a minimum age.

A net slip rate of $0.04-0.06 \mathrm{~mm} / \mathrm{yr}$ was obtained for FS1 at Gabarrones. It was only possible to obtain the net slip here because of the lack of good kinematic indicators at the other trenches. A net slip of 2.87-3.01 m was inferred from a vertical slip of $1.26-1.31 \mathrm{~m}$ at fault $\mathrm{b}$ $\left(087^{\circ} / 25^{\circ} \mathrm{S}\right.$ and $70^{\circ} \mathrm{W}$ pitch). The net slip rate obtained $(0.04-0.06 \mathrm{~mm} / \mathrm{yr})$ is much larger than the vertical $(0.02-0.03 \mathrm{~mm} / \mathrm{yr})$ and the strikeslip rates $(0.02 \mathrm{~mm} / \mathrm{yr})$. The wide range of slip vectors observed in the study area is likely to be the result of the structure formed by faultbounded blocks, which may induce space constrictions on the movements of the blocks. Therefore, it is not recommendable to use the net-to-dip slip relationship observed at Gabarrones to estimate the net slip at the other sites.

\section{Summed Slip Rates}

For the time range between 47 and $63 \mathrm{ka}$, the sum of the vertical slip rates of the Góñar strands 1, 2, and 3 in the northern area (Carrascos and Gabarrones sites) varies between 0.04 and $0.07 \mathrm{~mm} / \mathrm{yr}$, which is lower than the values obtained for the system in the southern sector (Era and Sardinas sites) of $0.07-0.12 \mathrm{~mm} / \mathrm{yr}$ (Table 4). This suggests that a greater accumulated vertical uplift has taken place in this area with respect to the northernmost sites. Such an increase in the vertical slip of the system is in agreement with the orientation of the fault traces that are more perpendicular to the NW-SE convergence direction (Fig. 1A). The total vertical slip of the Alhama de Murcia fault-Góñar fault system could double these values should a similar slip rate be attributed to the northern Alhama de Murcia fault and southern Alhama de Murcia fault. Such an assumption yields vertical slip values in the range of 0.16 and $0.22 \mathrm{~mm} / \mathrm{yr}$.

The total minimum strike-slip rate of the Alhama de Murcia fault-Góñar system was estimated between 0.95 and $1.37 \mathrm{~mm} / \mathrm{yr}$. This value was obtained by adding the rates of the northern Alhama de Murcia fault and the southern Alhama de Murcia fault to the sum of rates in the Góñar faults (Table 4). The latter value is close to $0.04 \mathrm{~mm} / \mathrm{yr}$, which is twice the strikeslip rate at Gabarrones, since the Góñar system in the Gabarrones transect is made up of two strands. The slip rates considered were obtained using markers of very different ages, which introduces considerable uncertainty. Such a total minimum value would be lower if the northern Alhama de Murcia fault were not active during the late Pleistocene-Holocene.

A further estimation of the summed slip rate was done by extrapolating the net slip rate obtained at Gabarrones $(0.04-0.06 \mathrm{~mm} / \mathrm{yr})$ to the remaining fault strands. This led to a total net slip rate of the Alhama de Murcia fault-Góñar 
fault system at the Gabarrones transect between 0.16 and $0.24 \mathrm{~mm} / \mathrm{yr}$, for the system here is made up of at least four fault strands.

The large difference between the summed slip rates obtained by these different approaches shows that these estimations have large uncertainties.

\section{Comparison of Slip Rates with Neighboring Fault Segments}

The summed vertical slip rates of the fault strands in the Alhama de Murcia faultGóñar fault system $(0.16-0.22 \mathrm{~mm} / \mathrm{yr}$ since 47-63 ka) are considerably greater than the values observed at the Albox fault ( 0.01 and $0.04 \mathrm{~mm} / \mathrm{yr}$; Masana et al., 2005) and are comparable or smaller than those observed at the central Alhama de Murcia fault at Lorca. There, Masana et al. (2004) reported vertical slip rates between 0.04 and $0.35 \mathrm{~mm} / \mathrm{yr}$ on the southern Alhama de Murcia fault strand for the last 30 k.y. (Table 1). This could represent half of the total vertical slip, which would range between 0.08 and $0.70 \mathrm{~mm} / \mathrm{yr}$ if the southern Alhama de Murcia fault rate is extrapolated to the northern Alhama de Murcia fault (Fig. 1B). A decrease in the vertical slip from the central parts of the Alhama de Murcia fault (at Lorca) toward the tips of the system (at Góñar) is suggested. A similar decrease is observed in the net slip rates. At the southern Alhama de Murcia fault in the Lorca trenches, the net slip rates for the last $30 \mathrm{k} . \mathrm{y}$. range between 0.53 and $0.66 \mathrm{~mm} / \mathrm{yr}$ (Masana et al., 2004), whereas at the Gabarrones transect, the rates vary between 0.16 and $0.24 \mathrm{~mm} / \mathrm{yr}$, assuming the deformation of the system is equally partitioned among four fault strands. This decrease of the vertical and net slip rates is consistent with the expected variations in slip from the center to the tips of the faults and would be compatible with the two sites being part of a single fault segment.

The strike-slip rates obtained at Lorca using the pitch of slickenlines on the southern Alhama de Murcia fault are $0.06-0.53 \mathrm{~mm} / \mathrm{yr}$. These values are comparable to or smaller than those obtained for the southern Alhama de Murcia fault and the northern Alhama de Murcia fault at Góñar (between 0.45 and $1.33 \mathrm{~mm} / \mathrm{yr}$ ). If smaller, the difference could be indicative of (1) a decrease in the activity of the fault with time, since the age of the markers used at Lorca (30 ka) is much younger than the age used for Góñar (100-175 ka and $750 \mathrm{ka}$ ) or (2) an overestimation of the slip rate at Góñar related to an underestimation of the age considered for the calculations. This latter possibility would invalidate the unusually large strike-slip rates for Góñar estimated previously herein, so that the decrease in the vertical slip rate from the cen- tral to the southern tip of the Alhama de Murcia fault would not be contradicted by the strikeslip rates. Smaller slip rates would also be more consistent with the recurrence period obtained in the next section.

\section{Paleoseismic Parameters}

\section{Slip per Event}

The northern Alhama de Murcia fault, the southern Alhama de Murcia fault, and the Góñar fault system form a horse-tail structure as suggested by the fault pattern (in map view) and the fault geometry, with the result that all the faults could be connected at depth. This implies that the different strands could all move simultaneously during an earthquake. In such a case, the slip per event observed at the trenches at the Gónar faults is a minimum value that could only represent one fourth of the total slip (or even less if the slip at the boundary faults is greater). The only trench for which the net slip was calculated is Gabarrones (event Ga-2). The net slip recorded, $1.15 \pm 0.25 \mathrm{~m}$, can be taken as a minimum slip per event associated with the system. A similar slip in the four strands of the system at the Gabarrones transect would mean a slip per event between 3.6 and $5.6 \mathrm{~m}$. In accordance with empirical relations proposed by Stirling et al. (2002), such single-event displacements are linked to faults that are $\sim 400 \mathrm{~km}$ long, whereas the Alhama de Murcia fault does not exceed $150 \mathrm{~km}$ in length. This suggests that (1) the slip is distributed in an irregular manner among the four strands of the system, or (2) the $1.15 \pm 0.25 \mathrm{~m}$ slip corresponds to more than one earthquake, or (3) the faults do not move simultaneously.

Another way of estimating the minimum slip per event is to consider the accumulated slip recorded at some of the trenches. For instance, at Tio Rey, the six paleoearthquakes could have been recorded in the large displacement of unit $\mathbf{J}$ by fault $b(6.72 \pm 0.74 \mathrm{~m}$ along the dip) as well as in the displacement along the other faults at this trench (Fig. 6E). This yields a slip along dip per event of $1.12 \pm 0.12 \mathrm{~m}$, which could be smaller if the number of paleoearthquakes represented were greater. In the Era trench, the vertical offset of the base of unit C1, 4.31-5.05 m, probably reflects the displacement of four to five earthquakes. According to the event chronologies (Fig. 7A), this number of earthquakes is the minimum number that occurred after the deposition of unit C1 (dated as 124-149 ka). These values yield maximum vertical slip per events between 0.86 and $1.26 \mathrm{~m}$ at FS5, which is over the range of the average slip per event observed at the paleoseismological sites in the region (Table 1 ).
The aforementioned estimates yielded vertical slips per event in the range of 1.7-2.8 m (twice the range of $0.86-1.4 \mathrm{~m}$ calculated for a single strand).

\section{Maximum Expected Earthquake Magnitude}

To estimate the maximum expected magnitude associated with the seismic rupture of the Alhama de Murcia fault-Góñar fault system, we used the length of the system rather than the slip per event observed at the trenches. The reason for this was twofold: (1) the large uncertainty associated with the values of slip per event observed, which in most cases did not correspond to the net slip, and (2) the fact that the slip is distributed among several fault strands, so that the real value cannot be well constrained.

The length of the traces of the Gónar fault system is $\sim 6 \mathrm{~km}$, which is a minimum estimate of the length of the Alhama de Murcia fault southern splay (see section on the southern tip of the Alhama de Murcia fault). The surface rupture of a $6 \mathrm{~km}$ fault can be related to an earthquake magnitude of $\mathrm{M}_{\mathrm{W}}=5.9$ by using the empirical relationships that Berryman et al. (2002) proposed for strike-slip and reverse faults in New Zealand. A similar value, $\mathrm{M}_{\mathrm{W}}=$ 6.0 , is obtained through the general equations of Wells and Coppersmith (1994). These magnitudes are slightly greater than the $\mathrm{M}_{\mathrm{W}}=5.6$ magnitude obtained using the Hanks and Bakun (2002) relationships for strike-slip earthquakes at global plate boundaries.

The coseismic rupture of the entire GóñarLorca fault segment $(40 \mathrm{~km})$ should also be considered. Given the lack of paleoseismological studies in the area between these localities, the possible propagation of a seismogenic rupture through the $40 \mathrm{~km}$ fault trace cannot be ruled out. Employing the aforementioned empirical relationships, such a fault rupture can be related to earthquakes with $\mathrm{M}_{\mathrm{w}}=7.0$ (equations in Berryman et al., 2002), $\mathrm{M}_{\mathrm{w}}=6.9$ (equation in Wells and Coppersmith, 1994), and $\mathrm{M}_{\mathrm{w}}=6.7$ (equations in Hanks and Bakun, 2002).

An alternative "intermediate" scenario is the coseismic rupture from Góñar to the area immediately north of Puerto Lumbreras (Fig. 1B), where a stepover in the fault trace could act as a barrier for the propagation of slip on the fault. In this case, the fault rupture length would be $\sim 15 \mathrm{~km}$, which can be related to earthquake magnitudes of $\mathrm{M}_{\mathrm{W}}=6.1-6.4$ according to the three aforementioned empirical relationships.

For these calculations, we used a rupture width of $12 \mathrm{~km}$, which is the most accepted value for the seismogenic crust in the area (García-Mayordomo, 2005).

The $6 \mathrm{~km}$ rupture length is the least probable among all the options discussed. It would be an 
unusually small length for a seismogenetic rupture in accordance with the values commonly observed (e.g., Wells and Coppersmith, 1994; Gasperini et al., 1999; Stirling et al., 2002), and at the same time, it would be related to average coseismic displacements much smaller ( $\sim 0.18 \mathrm{~m}$ according to equations in Wells and Coppersmith, 1994) than that expected for the Góñar system (more than 0.86-1.26 m).

These estimated magnitudes pose a significant risk in this area, where most of the towns are built on top of alluvial sediments that could trigger amplification of the seismic waves and liquefaction. This was shown to be crucial during the Lorca earthquake $\left(11 / 05 / 2011, \mathrm{M}_{\mathrm{w}}=\right.$ $5.1)$, which caused peak ground accelerations in the order of $0.36 \mathrm{~g}$ (IGN, 2011), i.e., three times greater than the value assigned to the area in the Spanish seismo-resistant construction code (NCSR-02, 2002).

\section{Recurrence Period}

A preliminary estimate of the maximum value of the mean recurrence period of the Góñar fault system can be obtained by considering the three options for the paleoearthquake chronology discussed in the foregoing section. In the three options, the four latest paleoearthquakes occurred within a maximum period of 108-116 k.y. Assuming a periodic behavior for the fault ruptures, we obtained an average time of 27-29 k.y. between two successive earthquakes. However, in options 1 and 3, paleoearthquake 4 could have occurred ca. 59-63 ka, which yields a recurrence period of 15-16 k.y. When considering the last six paleoearthquakes, the maximum recurrence period increases to $29-47 \mathrm{k}$.y. If only the last five paleoearthquakes are considered, the recurrence ranges from 27 to $42 \mathrm{k} . \mathrm{y}$.

Summarizing, the maximum recurrence period yielded ranges between 15 and 29 k.y. for the last 108-116 k.y. The minimum value is similar to the recurrence interval obtained at the Lorca trenches (ca.14 k.y.; Masana et al., 2004), whereas the maximum value approximately doubles it. The 15-29 k.y. range for the recurrence interval is, at any case, larger than the $\sim 8$ k.y. recurrence interval obtained from a maximum total slip rate of $0.24 \mathrm{~mm} / \mathrm{yr}$ and a minimum of $\sim 2 \mathrm{~m}$ of summed slip per event deduced for the system. This latter value is a robust estimation of the minimum summed slip as observed in the trenches. Therefore, such a discrepancy could be due to an underestimation of the number of paleoearthquakes, which in any case is considered as a minimum, and/or to an overestimation of the total slip rate of the system.

The rough estimate of the recurrence period made here relates to the large uncertainties associated with the time constraints of the events, i.e., the result of the large time difference between the units bracketing the events. Since this is related to the discontinuous sedimentological record that characterizes the study area, this aspect constitutes a major limitation. A better estimate of the real recurrence period in the area, however, could be obtained with paleoseismic data from other sites along the studied fault strands and from the northern and southern Alhama de Murcia fault strands.

\section{Insights into the Geodynamics of the Alhama de Murcia fault-Góñar System}

The structure observed at the southern tip of the Alhama de Murcia fault, which is made up of a splay of synthetic and antithetic faults, can be explained by two models: (1) The structure is inherited from the earlier extensional tectonic regime. Similar splay geometries have been observed at the tip of extensional systems within continental crust by Bahat (1981) and Suter et al. (1992), among others. (2) The structure corresponds to a horse-tail termination generated by the growth of the Alhama de Murcia fault as a strike-slip structure, active since the latest Miocene. Whichever its origin, we documented a significant component of reverse slip in this part of the Alhama de Murcia fault, where the structure changes its orientation. The strike-slip component of the inner faults of the splay (the Góñar faults) is minor compared to the reverse slip.

The southwestern tip of the Alhama de Murcia fault seems to behave like a compressional bend in which the strike of the faults undergoes a clockwise rotation that favors a larger shortening component under the NNW-SSE $\mathrm{S}_{\text {hmax }}$ direction. A similar geometry is observed in the central part of the Alhama de Murcia fault in the Lorca-Totana segment (Martínez-Díaz, 1998; Martínez-Díaz et al., 2003; Masana et al., 2004) and in the neighboring northeastern tip of the Carrascoy fault (Fig. 1), as described by GarcíaMayordomo and Martínez-Díaz (2006). The NNW-SSE $S_{\text {hmax }}$ differs from the interplate NWSE convergence azimuth proposed by Argus et al. (1989) for this interplate transect. This could be due to an inland rotation of the convergence direction or to local variations in the maximum horizontal compression. The latter situation is expected when the interplate deformation is accommodated through structures that are inherited from previous tectonic regimes and that show a variety of orientations.

\section{CONCLUSIONS}

In this study, we present an 300-k.y.-long paleoseismic chronology of a slow-moving fault zone, the southern tip of the Alhama de Murcia fault. This is one of the longest paleoseismic records obtained to date. Since slow-moving faults are characterized by long recurrence intervals (greater than tens of thousands of years), the time observation window required to observe several successive earthquakes is in the order of hundreds of thousands of years.

A number of factors contributed to the study of this long paleoseismic history:

(1) The presence of a splay structure. This structure showed simultaneous rupture along its fault strands, which provided us with more opportunities to refine the time constraints for the recorded paleoearthquakes. This could not have been done in a single structure or at a single paleoseismic site.

(2) The possibility of dating units as old as $325 \mathrm{ka}$ by a new luminescence dating protocol developed by Sohbati et al. (2011). This new technique, which measures the luminescence radiation on $\mathrm{K}$-feldspar grains, extends the range for numerical dating of Quaternary sediments, which is usually limited to younger than $100 \mathrm{ka}$.

(3) The alluvial sedimentary environment with a condensed (although not continuous) sedimentation. Such a sedimentological setting combined with a faulting style consisting of oblique-reverse faulting and fault-propagation folding enabled the observation of different alluvial-fan phases in relatively shallow trenches (of less than $3 \mathrm{~m}$ depth).

We documented a fault zone $(1.5 \mathrm{~km}$ wide and minimum length of $6 \mathrm{~km}$ long) made up of four to five fault strands. The deformation has been partitioned into the different strands. The overall structure is characterized by (1) oblique slip with reverse and left-lateral movement, (2) slip rates between 0.03 and $0.12 \mathrm{~mm} / \mathrm{yr}$ in the internal structures (Góñar faults), and between 0.16 and $0.24 \mathrm{~mm} / \mathrm{yr}$ for the Alhama de Murcia fault-Góñar system, which includes the northern Alhama de Murcia fault and the southern Alhama de Murcia fault. The activity along the fault system has given rise to a compressional bend between the uplifted Las Estancias range and the Huercal-Overa and Guadalentin depressions. This deformation forms a smaller secondary range front that emerges in the Guadalentin Basin, conditioning the draining network. A possible foreland migration of the deformation is observed.

The paleoseismologic data provided new insights into the segmentation of the Alhama de Murcia fault. The integrated analysis of the event chronologies at six different trenches yielded a minimum of six paleoearthquakes during the last 174-274 k.y., with a maximum recurrence interval between 15 and 29 k.y. for the last 59-116 k.y. Correlation of the paleoearthquakes at the southwestern tip of the Alhama de 
Murcia fault with those previously observed in the central part (Lorca) and at the neighboring Albox fault indicates a feasible synchronicity of the fault ruptures, which suggests that a maximum $\mathbf{M}_{\mathrm{w}}=7$ earthquake could occur in the area. These results should be considered in the seismic hazard assessment of the region. This is of paramount importance in this part of the Iberian Peninsula, where movement in the central segment of the Alhama de Murcia fault recently produced a shallow $\mathrm{M}_{\mathrm{w}}=5.1$ earthquake (11 May 2011), leaving thousands of people homeless and causing considerable economic loss.

\section{ACKNOWLEDGMENTS}

This work was funded by the Spanish Ministerio de Educación y Ciencia through the EVENT (CGL2006-12861-C02-01/BTE) and the SHAKE (CGL2011-30005-C02-01/BTE) projects, the Consolider-Ingenio 2010 program, under CSD2006-0004 "Topo-Iberia," and in part by the project PTDC/ CTE-GIN/66283/2006 (approved by the FCT and co-funded by FEDER [European Fund for Regional Development]). We would like to express our gratitude to Y. Vázquez, R. Roper, A. Caro, and O. Romero for their field assistance and to the R. Ayala family, to David and Dora, and to M. Peralta of Góñar. We are very grateful to A. Soler (Departamento de Desertificación y Geoecología, CSIC [Spanish National Research Council] España) and to P. Ruano (Departamento de Geologia, Universidad de Granada) for their helpful discussions in the field. The thermoluminescence dating was carried out by Quaternary TL Surveys (Nottingham, UK), and the optically stimulated luminescence dating was carried out at the Earth Sciences Department, Universidade de Coimbra (sample treatment) and at the Nordic Laboratory for Luminescence Dating of Aarhus University (OSL measurements). The final version of the paper was improved considerably thanks to the reviews and suggestions made by Pilar Villamor and John Wakabayashi.

\section{REFERENCES CITED}

Argus, D.F., Gordon, R.G., DeMets, C., and Stein, S., 1989, Closure of the Africa-Eurasia-North American plate motion circuit and tectonics of the Gloria fault: Journal of Geophysical Research, v. 94, p. 5585-5602, doi:10.1029/JB094iB05p05585.

Bahat, D., 1981, Certain mechanical aspects in comparative continental rifting with special reference to the Baikal rift: Geological Magazine, v. 118, p. 271-280, doi:10.1017/S0016756800035755

Banda, E., and Ansorge, J., 1980, Crustal structure under the central and eastern part of the Betic Cordillera: Geophysical Journal of the Royal Astronomical Society, v. 63, p. 515-532, doi:10.1111/j.1365-246X.1980 .tb02635.x.

Bardají, T., 1999, Evolución Geodinámica de la Cuencas Neógenas del Litoral de Murcia y Almería durante el Cuaternario [Ph.D. thesis]: Madrid, Spain, Universidad Complutense de Madrid, $457 \mathrm{p}$.

Berryman, K., Webb, T., Hill, N., Stirling, M., Rhoades, D., Beavan, J., and Darby, D., 2002, Seismic Loads on Dams, Waitaki System. Earthquake Source Characterisation: Main Report, New Zealand Institute of Geological and Nuclear Sciences (GNS) Client Report 2001/129, 80 p.

Bousquet, J.C., 1979, Quaternary strike-slip faults in southeastern Spain: Tectonophysics, v. 52, p. 277-286, doi:10.1016/0040-1951(79)90232-4

Bousquet, J.C., and Montenat, C., 1974, Presence de décrochements NE-SW Plio-Quaternaires dans les Cordillères
Bétiques Orientales (Espagne). Extension et signification general: Comptes Rendues de l'Academic des Sciences, Paris, v. 278, p. 2617-2620.

Briend, M., 1981, Evolution Morpho-Tectonique du Basin Neogene de Hu'ercal Overa (Cordilleres Betiques Orientales-Espagne): Documents et Travaux, IGAL (Institut Géologique Albert de Lapparent) 4, 208 p.

Buylaert, J.P., Murray, A.S., Thomsen, K.J., and Jain, M., 2009, Testing the potential of an elevated temperature IRSL signal from K-feldspar: Radiation Measurements, v. 44, p. 560-565, doi:10.1016/j.radmeas.2009.02.007.

De Mets, Ch., Gordon, R.G., Argus, D.F., and Stein, S., 1994, Effect of recent revisions to the geomagnetic reversal time scale on estimates of current late motions: Geophysical Research Letters, v. 21, p. 2191-2194, doi:10.1029/94GL02118.

García-Mayordomo, J., 2005, Caracterización y Análisis de la Peligrosidad Sísmica en el Sureste de España [Ph.D. thesis]: Madrid, Spain, Universidad Complutense de Madrid, $373 \mathrm{p}$.

García-Mayordomo, J., and Martínez Díaz, J., 2006, Caracterización sísmica del anticlinorio del Bajo Segura (Alicante): Fallas del Bajo Segura, Torrevieja y San Miguel de Salinas: Geogaceta, v. 40, p. 19-22.

García-Meléndez, E., 2000, Geomorfología y Neotectónica del Cuaternario de la Cuenca de Huércal-Overa y Corredor del Almanzora. Análisis y Cartografía mediante Teledetección y SIG [Ph.D. thesis]: Salamanca, Spain, Universidad de Salamanca, $528 \mathrm{p}$.

García-Meléndez, E., Goy, J.L., and Zazo, C., 2003, Neotectonica and Plio-Quaternary landscape development within the eastern Huércal-Overa Basin (Betic Cordilleras, southeastern Spain): Geomorphology, v. 50, p. 111-133, doi:10.1016/S0169-555X(02)00210-6.

García-Meléndez, E., Goy, J.L., and Zazo, C., 2004, Quaternary tectonic activity in the Huércal-Overa Basin (Almería, southeast Spain): Deformations associated with the Albox fault: Geogaceta, v. 36, p. 63-66.

Gasperini, P., Bernardini, F., Valensise, G., and Boschi, E., 1999, Defining seismogenic sources from historical earthquake felt reports: Bulletin of the Seismological Society of America, v. 89, no. 1, p. 94-110.

Gauyau, F., Bayer, R., Bousquet, J.C., Lachaud, J.C., Lesquer, A., and Montenat, C., 1977, Le prolongament de l'accident d'Alhama de Murcia entre Murcia et Alicante (Espagne résultats d'une étude géophysique méridionale): Bulletin de la Société Géologique de France, Série 7, v. 19, p. 623-629.

Hanks, T.C., and Bakun, W.H., 2002, A bilinear sourcescaling model for M- $\log \mathrm{A}$ observations of continental earthquakes: Bulletin of the Seismological Society of America, v. 92, p. 1841-1846, doi:10.1785 /0120010148.

IGN (Instituto Geográfico Nacional de España), 2010, Servicio de Información Sísmica del Instituto Geográfico Nacional de España: http://www.ign.es/ign/es/IGN /SisIndice.jsp (accessed November 2010).

IGN (Instituto Geográfico Nacional de España), 2011, Serie Sísmica del Terremoto de Lorca, Murcia (11/05/2011): http://www.ign.es/ign/resources/sismologia/Lorca.pdf (accessed January 2012).

Martínez-Díaz, J.J., 1998, Neotectónica y Tectónica Activa del Sector Centro-Occidental de la Region de Murcia y Sur de Almería (Cordillera Bética, España) [Ph.D. thesis]: Madrid, Spain, Universidad Complutense de Madrid, $466 \mathrm{p}$

Martínez-Díaz, J.J., Masana, E., Hernández-Enrile, J.L., and Santanach, P., 2001, Evidence for coseismic events of recurrent prehistoric deformation along the Alhama de Murcia fault, southeastern Spain: Acta Geológica Hispánica, v. 36, p. 315-327.

Martínez-Díaz, J.J., Masana, E., Hernández-Enrile, J.L., and Santanach, P., 2003, Effects of repeated paleoearthquakes on the Alhama de Murcia fault (Betic Cordillera, Spain) on the Quaternary evolution of an alluvial fan system: Annals of Geophysics, v. 46, no. 5, p. 775-792.

Martínez-Díaz, J.J., Masana, E., and Ortuño, M., 2012a, Active tectonics of the Alhama de Murcia fault, Betic Cordillera, Spain: Journal of Iberian Geology, v. 38 no. 1 , p. 269-286, doi:10.5209/rev JIGE.2012.v38 .n1.39218.
Martínez-Díaz, J.J., Bejar-Pizarro, M., Álvarez-Gómez, J.A., Mancilla, F.L., Stich, D., Herrera, G., and Morales, J., 2012b, Tectonic and seismic implications of an intersegment rupture: Tectonophysics (in press), doi:10.1016/j.tecto.2012.04.010.

Masana, E., Martínez-Díaz, J.J., Hernández-Enrile, J.L., and Santanach, P., 2004, The Alhama de Murcia fault (SE Spain), a seismogenic fault in a diffuse plate boundary: Seismotectonic implications for the Ibero-Magrebian region: Journal of Geophysical Research, v. 109, p. 1-17, doi:10.1029/2002JB002359.

Masana, E., Pallàs, R., Perea, H., Ortuño, M., MartínezDíaz, J.J., García-Meléndez, E., and Santanach, P. 2005, Large Holocene morphogenic earthquakes along the Albox fault, Betic Cordillera, Spain: Journal of Geodynamics, v. 40, p. 119-133, doi:10.1016 /j.jog.2005.07.002.

McCalpin, J.P., 1996, Paleoseismology: San Diego, California, Academic Press, $588 \mathrm{p}$

McClusky, S., Reilinger, R., Mahmoud, S., Ben Sari, D. and Tealeb, A., 2003, GPS constraints on Africa (Nubia) and Arabia plate motions: Geophysical Journal International, v. 155 , p. 126-138, doi: 10.1046 /j.1365-246X.2003.02023.x.

Meijninger, B.M.L., 2006, Late-Orogenic Extension and Strike-Slip Deformation in the Neogene of Southeastern Spain [Ph.D. thesis]: Utrecht, Netherlands, Universiteit Utrecht, Geologica Ultraiectina, 179 p.

Montenat, C., 1973, Les Formations Néogènes du Levant Espagnol [Ph.D. thesis]: Orsay, France, University of Paris, $1170 \mathrm{p}$.

Montenat, C., 1996, The Betic Neogene basins: Introduction, in Friend, P.F., and Dabrio, C., eds., Tertiary Basins of Spain: Cambridge, Cambridge University Press, p. 321-322.

Montenat, C., and Ott d'Estevou, P., 1996, Late Neogene basins evolving in the Eastern Betic transcurrent faul zone: An illustrated review, in Friend, P.F., and Dabrio, C., eds., Tertiary Basins of Spain: Cambridge, Cambridge University Press, p. 372-386.

Montenat, C., Ott D'Estevou, P., and Masse, P., 1987, Tectonic-sedimentary characters of the Betic Néogène Bassins evolving in a crustal transcurrent shear zone (SE Spain): Bull. Centres. Rech. Explo. Prod. Elf Aquitaine., v. 11, no. 1, p. 1-22.

NCSR-02, 2002, Norma de Construcción Sismorresistente NCSE-02: Parte General y Edificación: Anexo al Rea Decreto 997/2002 de 27 de Septiembre: Madrid, BOE (Spanish Official Bulletin) (Spanish Government) no. 244 : Sábado 11 de Octubre de 2002, p. 35,898-35,967.

Pedrera, A., Galindo-Zaldivar, J., Tello, A., and MarinLechado, C., 2010, Intramontane basin development related to contractional and extensional structure interaction at the termination of a major sinistral fault: The Huercal-Overa Basin (Eastern Betic Cordillera): Journal of Geodynamics, v. 49, no. 5, p. 271-286, doi:10.1016/j.jog.2010.01.008

Rodríguez-Fernández, J., and Sanz de Galdeano, C., 1992 Onshore Neogene stratigraphy in the north of the Alboran Sea (Betic internal zones): Paleogeographic implications, in Madonado, A., ed., The Alboran Sea: Geo-Marine Letters, v. 12, no. 2/3, p. 123-128.

Sanz de Galdeano, C., 1990, Geologic evolution of the Betic Cordilleras in the Western Mediterranean, Miocene to present: Tectonophysics, v. 172, p. 107-119, doi:10.1016/0040-1951(90)90062-D

Sanz de Galdeano, C., and Vera, J.A., 1992, Stratigraphic record and palaeogeographical context of the Neogene basins in the Betic Cordillera, Spain: Basin Research, v. 4, p. 21-36, doi:10.1111/j.1365-2117.1992 .tb00040.x.

Silva, P., 1994, Evolución Geodinámica de la Depresión del Guadalentín desde Mioceno Superior hasta la Actualidad: Neotectónica y Geomorfología [Ph.D. thesis]: Madrid, Spain, Universidad Complutense de Madrid, 642 p.

Silva, P., Goy, J.L., and Zazo, C., 1992a, Características estructurales y geométricas de la falla de desgarre de Lorca-Alhama: Geogaceta, v. 12, p. 7-10.

Silva, P., Goy, J.L., and Zazo, C., 1992b, Discordancias progresivas y expresión geomorfológica de los abanicos aluviales cuaternarios de la de presión tectónica del Guadalentín: Geogaceta, v. 11, p. 67-70. 
Silva, P.G., Goy, J.L., Somoza, L., Zazo, C., and Bardají, T., 1993, Landscape response to strike-slip faulting linked to collisional settings: Quaternary tectonics and basin formation in the Eastern Betics, southeast Spain: Tectonophysics, v. 224 , p. 289-303, doi:10.1016/0040-1951(93)90034-H

Silva, P.G., Goy, J.L., Zazo, C., Lario, J., and Bardají, T., 1997, Paleoseismic indications along "aseismic" fault segments in the Guadalentín depression (SE Spain): Journal of Geodynamics, v. 24, p. 105-115 doi:10.1016/S0264-3707(97)00011-2.

Silva, P.G., Goy, J.L., Zazo, C., and Bardají, T., 2003 , Fault-generated mountain fronts in southeast Spain: Geomorphologic assessment of tectonic and seismic activity: Geomorphology, v. 50, p. 203-225, doi:10.1016/S0169-555X(02)00215-5.

Sohbati, R., Murray, A.S., Buylaert, J.-P., Ortuño, M. Cunha, P.P., and Masana, E., 2011, Luminescence dating of Pleistocene alluvial sediments affected by the Alhama de Murcia fault (Eastern Betics, Spain)-A comparison between OSL, IRSL and post-IR IRSL ages: Boreas, v. 41, no. 2, p. 250-262, doi:10.1111 /j.1502-3885.2011.00230.x.

Soler, R., Masana, E., and Santanach, P., 2003, Evidencias geomorfológicas y estructurales del levantamiento tectónico reciente en la terminación sudoccidental de la falla de Alhama de Murcia (Cordillera Bética Oriental): Revista de la Sociedad Geológica de España, v. 16, no. 3/4, p. 123-133.

Stirling, M., Rhoades, D., and Berryman, K., 2002, Comparison of earthquake scaling relations derived from data of the instrumental and reinstrumental era: Bulletin of the Seismological Society of America, v. 92 , p. 812-830, doi:10.1785/0120000221.

Suter, M., Quintero, O., and Johnson, C.A., 1992, Active faults and state of stress in the central part of the transMexican volcanic belt: 1 . The Venta del Bravo fault: Journal of Geophysical Research, v. 97, p. 11,98311,993, doi:10.1029/91JB00428.

Thomsen, K.J., Murray, A.S., Jain, M., and Bøtter-Jensen, L., 2008 , Laboratory fading rates of various luminescence signals from feldspar-rich sediment extracts: Radia- tion Measurements, v. 43, p. 1474-1486, doi:10.1016 jj.radmeas.2008.06.002

Voermans, F.M., Geel, T., and Baena, J., 1978, Mapa Geológico de España 1:50.000, Hoja Velez-Rubio (no. 974): Madrid, Spain, Instituto Geológico y Minero de España, scale 1:50,000

Wells, D.L., and Coppersmith, K.J., 1994, New empirical relationships among magnitude, rupture length, rupture area and surface displacement: Bulletin of the Seismological Society of America, v. 84, p. 974-1002.

SCIEnce Editor: Christian Koeberl Associate Editor: John WaKabayashl

Manuscript Received 29 May 2011

Revised Manuscript Received 3 February 2012

MANUSCRIPT ACCEPTED 7 FEBRUARY 2012

Printed in the USA 